\title{
Integrated acoustic and coring investigation of glacigenic deposits in Spitsbergen fjords
}

\author{
Liv Plassen, Tore O. Vorren \& Matthias Forwick
}

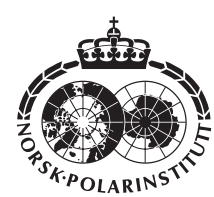

In many areas of Svalbard, the Neoglacial terminal deposits represent the Holocene glacial maximum. The glaciers began the retreat from their Neoglacial maximum positions around 1900 AD. Based on high resolution acoustic data and sediment cores, sedimentation patterns in four tidewater glacier-influenced inlets of the fjord Isfjorden (Tempelfjorden, Billefjorden, Yoldiabukta and Borebukta), Spitsbergen, were investigated. A model for sedimentation of tidewater glaciers in these High Arctic environments is proposed. Glacigenic deposits occur in proximal and distal basins. The proximal basins comprise morainal ridges and hummocky moraines, bounded by terminal moraines marking the maximum Neoglacial ice extent. The distal basins are characterized by debris lobes and draping stratified glacimarine sediments beyond, and to some extent beneath and above, the lobes. The debris lobe in Tempelfjorden is composed of massive clayey silt with scattered clasts. Distal glacimarine sediments comprise stratified clayey silt with low ice-rafted debris (IRD) content. The average sedimentation rate for the glacimarine sediments in Tempelfjorden is $17 \mathrm{~mm} / \mathrm{yr}$ for the last ca. 130 years. It is suggested that the stratified sediments in Tempelfjorden are glacimarine varves. The high sedimentation rate and low IRD content are explained by input from rivers, in addition to sedimentation from suspension of glacial meltwater. The debris lobes in Borebukta are composed of massive clayey silt with high clast content. Distal glacimarine sediments in Yoldiabukta comprise clayey silt with high IRD content. The average sedimentation rate for these sediments is $0.6 \mathrm{~mm} / \mathrm{yr}$ for the last 2300 years.

L. Plassen, Norwegian Geological Survey, Polar Environmental Centre, NO-9296 Tromsø, Norway, liv. plassen@ngu.no; T. O. Vorren \& M. Forwick, Dept. of Geology, University of Tromsø, NO-9037 Tromsø, Norway.

This paper concerns the sedimentary processes and products associated with four tidewater glacier-dominated inlets of the fjord Isfjorden, Spitsbergen: Tempelfjorden, Billefjorden, Yoldiabukta and Borebukta (Fig. 1). The study is based on high resolution acoustic data and sediment cores.

About $60 \%$ of the Svalbard archipelago is covered by glaciers, many of which terminate in fjords as tidewater glaciers. Most of the present Svalbard glaciers are referred to as polythermal (Hagen et al. 1993; Hambrey et al. 1999), and many of them surge (Liestøl 1969; Jiskoot et al. 2000). Environmental factors controlling surges are not fully understood, and advances related to surges are not necessarily climatically induced (e.g. Hamilton \& Dowdeswell 1996).

The inner parts of Isfjorden were deglaciated around $10{ }^{14} \mathrm{C}$ Kya (thousands of radiocarbon years ago) (Svendsen et al. 1996). During the early and mid-Holocene, the inner parts of Isfjorden were probably not influenced by tidewater glaciers (Svendsen \& Mangerud 1997). The Neogla- 


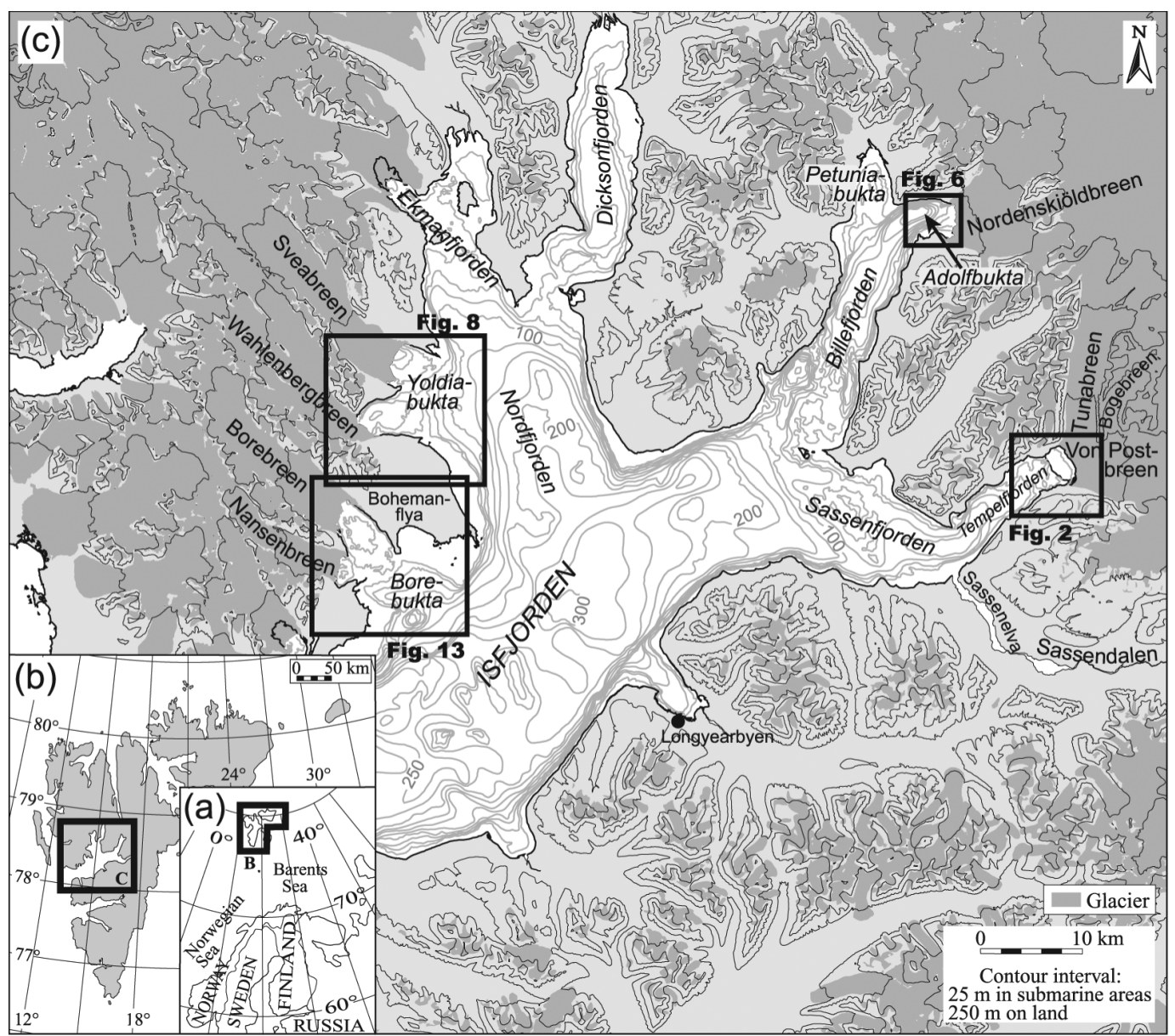

Fig. 1. (a, b) Location maps. (c) Map of the Isfjorden area. Boxes refer to study areas.

cial major readvance of the glaciers commenced during the late Holocene, about $4{ }^{14} \mathrm{C}$ Kya (Svendsen \& Mangerud 1997), culminating in maximum glacier extents at different times (Werner 1993; Svendsen \& Mangerud 1997; Huddart \& Hambrey 1996). Expedition charts (De Geer 1910) and moraines mapped from aerial photographs show marked glacier retreat in Isfjorden during the 20th century. In the Isfjorden area, prominent distal sediment wedges of $>40 \mathrm{~m}$ thickness mark the terminal moraines deposited during the maximum glacier extent of the Neoglacial (Elverhøi et al. 1995). These authors have mapped a sediment volume of $22.5 \mathrm{~km}^{3}$ that has accumulated in Isfjorden since the deglaciation, i.e. during the last $13{ }^{14} \mathrm{C} \mathrm{Ky}$ (thousands of radiocarbon years).

Subglacial meltwater streams, as well as calved icebergs provide the main sources of water and sediment to the Spitsbergen fjord systems (Dowdeswell 1989). Stratified, draping sediments, 10-20 m thick, are present in the main fjord basins (Elverhøi et al. 1995). Glacimarine environments are commonly characterized by stratified sediments (as discussed by Ó Cofaigh \& Dowdeswell 2001). These include varves, which reflect seasonal changes in deposition (e.g. Elverhøi et al. 1980; Cowan et al. 1997; Stevens 1990; Gilbert 2003) and, for example, tidal rhythmites reflecting more rapid variations (e.g. Mackiewicz et al. 1984; Powell \& Molnia 1989; Cowan et al. 1999; Gilbert et al. 2002).

Models for the evolution of marine ice-contact fans and deltas have been proposed by several authors (e.g. Boulton 1986; Powell 1990; Lønne 1995; Lyså \& Vorren 1997). However, little attention has been paid to the landforms and sediment 
assemblages that result from the rapid advance of tidewater glaciers, either due to a surge, or simply as a result of the non-climatic ice-marginal fluctuations common to tidewater glaciers (Warren 1992).

The seismic character can be interpreted in terms of the processes influencing deposition in the fjord complex and the known history of tidewater glacier fluctuations (Sexton et al. 1992). The aim of our study is to evaluate the sedimentary systems of the four tidewater glacier-influenced inlets Tempelfjorden, Billefjorden, Yoldiabukta and Borebukta (Fig. 1), and to propose a model for glacigenic sedimentation of surging and nonsurging tidewater glaciers in a High Arctic environment. Furthermore, we briefly discuss the chronology of Holocene glacier advances.

All these inlets are tributaries to Isfjorden, which is the largest fjord in western Spitsbergen (Fig. 1). It has a length of $100 \mathrm{~km}$ and a maximum depth of $425 \mathrm{~m}$. The catchment area is $7309 \mathrm{~km}^{2}$, of which $40 \%$ is covered by glaciers (Hagen et al. 1993). Tidewater glaciers occur in the northern and eastern branches of Isfjorden (Fig. 1). The glacier termini are grounded (Dowdeswell et al. 1984).

\section{Material and methods}

This study was based on high resolution acoustic data (seismic and side-scan sonar) and sediment cores collected from the University of Tromsø's research vessel the Jan Mayen, using a Global Positioning System for navigation. Bathymetric data collected by the Norwegian Hydrographic Office, as well as topographic maps and aerial photographs from the Norwegian Polar Institute were used.

The acoustic data included $3.5 \mathrm{kHz}$ and sparker profiles, acquired in 1997, and $3.5 \mathrm{kHz}$ and boomer profiles, in addition to side-scan sonar

Table 1. Locations, sampling depths and core lengths of the sediment cores.

\begin{tabular}{ccccc}
\hline $\begin{array}{c}\text { Core iden- } \\
\text { tification }\end{array}$ & $\begin{array}{c}\text { Latitude } \\
(\mathrm{N})\end{array}$ & $\begin{array}{c}\text { Longitude } \\
(\mathrm{E})\end{array}$ & $\begin{array}{c}\text { Water depth } \\
(\mathrm{m})\end{array}$ & $\begin{array}{c}\text { Core length } \\
(\mathrm{cm})\end{array}$ \\
\hline JM97-937 & $78^{\circ} 25.01^{\prime}$ & $17^{\circ} 09.40^{\prime}$ & 66 & 318 \\
JM97-938 & $78^{\circ} 24.80^{\prime}$ & $17^{\circ} 07.05^{\prime}$ & 76 & 415 \\
JM98-812 & $78^{\circ} 28.43^{\prime}$ & $1^{\circ} 40.65^{\prime}$ & 78 & 197 \\
JM98-816 & $78^{\circ} 20.52^{\prime}$ & $14^{\circ} 30.09^{\prime}$ & 71 & 200 \\
\hline
\end{tabular}

data, acquired in 1998. The total profiling distance of the acoustic data was $190 \mathrm{~km}$. The acoustic system consisted of: (a) $10 \mathrm{~kW}$ hull-mounted Geoacoustic/Ferranti O.R.E. $3.5 \mathrm{kHz}$ penetration echo sounder (bandpass filter setting $3-5 \mathrm{kHz}$ ); (b) 300 J O.R.E. Model 5813A boomer (bandpass filter setting 500-1500 Hz); (c) $800 \mathrm{~J}$ Bennex multi-electrode sparker (bandpass filter setting $150-700 \mathrm{~Hz}$ ); (d) $100 \mathrm{kHz}$ O.R.E. side-scan sonar. A single channel Fjord Instruments streamer was used as the receiver for (b) and (c).

The seismic interpretation is based on laterally persistent high amplitude reflections that define boundaries between acoustic units. Acoustic attributes, bedding style and geometry give information about sediment properties, depositional processes and environments (e.g. Syvitski \& Praeg 1989), and the intensity of the grey tone between reflections determines the degree of acoustic transparency on the $3.5 \mathrm{kHz}$ records (King 1967).

When the sediment thickness in metres is mentioned, it is calculated from an assumed acoustic velocity of $1700 \mathrm{~m} / \mathrm{s}$. This was chosen as an average from measured values of about $1600 \mathrm{~m} / \mathrm{s}$ for surge-distal sediments, and about $1800 \mathrm{~m} / \mathrm{s}$ for surge moraines (Solheim 1991). Autocad 13 software, with the surface modelling system QuickSurf 5.2, was used to estimate sediment volumes and areas.

Four gravity cores were recovered in 1997 and 1998 (Table 1). The gravity corer had a weight of $1600 \mathrm{~kg}$ and an inner diameter of $11 \mathrm{~cm}$. Laboratory analysis included Multi-sensor core-logging, interpretation of X-radiographs, visual description (using Munsell Soil Color Chart), determination of water content, shear strength and carbonate content, as well as grain size analysis (wet-sieving and Sedigraph). Bivalves from core JM98-812 were sampled for accelerator mass spectrometry (AMS) radiocarbon age determination. The samples were prepared at the Radiological Dating Laboratory in Trondheim, Norway, and the measurements were carried out at the $\mathrm{T}$. Svedborg Laboratory in Uppsala, Sweden. Radiocarbon ages were corrected for a reservoir effect equal to 440 years (Mangerud \& Gulliksen 1975). The dates were calibrated using the 1998 marine calibration dataset with $\Delta \mathrm{R}=491 \pm 24$ (Stuiver et al. 1986; Stuiver et al. 1998). 


\section{Results}

\section{Tempelfjorden}

The tidewater glacier Tunabreen (north) and the land-based glacier Von Postbreen (south) merge at the head of Tempelfjorden (Figs. 1, 2a). A surge was recorded at Von Postbreen in 1870 AD, while Tunabreen had recorded surges in $1930 \mathrm{AD}$ and 1970 AD (Hagen et al. 1993). Bogebreen, an upglacier tributary to Von Postbreen, had a recorded surge in 1980 AD. De Geer (1910) mapped the maximum position of the 1870 surge of Von Postbreen, and its retreat positions until $1908 \mathrm{AD}$, as indicated in Fig. 2a. The maximum position of the 1870 surge corresponds well with the subaerial frontal moraine at the southern fjord margin and with the "Little Ice Age" moraine described by Elverhøi et al. (1995), as well as with the crest of the ice-marginal deposits mapped in this study (Fig. 3a). The two recorded surges of Tunabreen (1930 AD and 1970 AD) have probably not reached the 1870 maximum position (Fig. 2a). During the 1930 surge, the glacier snout advanced about $3 \mathrm{~km}$ (Liestøl 1969), and the 1971 glacier front was about $1 \mathrm{~km}$ infjord from this position.

The ice-marginal deposits in Tempelfjorden have a minimum volume of $0.32 \mathrm{~km}^{3}$, and extend about $6 \mathrm{~km}$ from the present glacier front (Fig. $2 b$, Table 2). The crest of the deposits, representing the Neoglacial terminal moraine, is located 4 to $4.5 \mathrm{~km}$ beyond the present glacier front. This moraine has a thickness of up to $70 \mathrm{~m}$. Three morainal ridges are present just proximal to the terminal moraine (Fig. 3c). Further towards the present glacier terminus, additional morainal ridges occur (Fig. 3a).

On the distal slope of the terminal moraine, a debris lobe was deposited. Two reflections, one about $500 \mathrm{~m}$ inside the outer margin of the debris lobe (Fig. 3b), and a discontinuous reflection through the deposit (Fig. 3a), can be identified. The distal part of the debris lobe is covered with ca. $2.5 \mathrm{~m}$ of acoustically stratified sediment (Figs. $3 b, 4)$. The proximal part has no discernible sediment cover (Fig. 3b).

Core JM97-937. Core JM97-937 is located on the distal part of the debris lobe in Tempelfjorden, about $300 \mathrm{~m}$ inside the lobe margin (Figs. 2b, 3b, 4, Table 1). The core is $318 \mathrm{~cm}$ long and is divided into two lithological units, 937-1 and $937-2$ (Fig. 5a).

Unit 937-1 (0-223 cm) comprises ca. 130 sub- horizontal couplets of reddish brown and dark to very dark greyish brown clayey silt with scattered clasts. The thickness of the individual couplets varies from ca. $2 \mathrm{~mm}$ to $50 \mathrm{~mm}$. The boundaries between the couplets are predominantly gradational. Black mottles $(<5 \mathrm{~mm}$ diameter) are scattered throughout the whole unit. Grain size analysis shows that the matrix of the reddish brown strata is slightly coarser than the more greyish ones. Undrained shear strength and density increase downcore. Marked peaks in the density log are caused by clasts. Water content generally decreases from the top of the unit to its base. Magnetic susceptibility increases irregularly downcore.

Colour changes, as well as a marked increase in undrained shear strength and magnetic susceptibility, define the boundary between units 9371 and 937-2. Unit 937-2 $(223-318 \mathrm{~cm})$ is predominantly composed of massive dark to very dark greyish brown clayey silt. However, a few thin $(<1 \mathrm{~cm})$, more reddish brown strata occur. Clasts are scattered throughout the unit, which is characterized by abundant black mottles. Furthermore, the uppermost $9 \mathrm{~cm}$ are slightly deformed. Undrained shear strength shows a marked increase downwards throughout unit 937-2. Water content remains constant in the upper half, but decreases toward the base. Density increases slightly downwards. Magnetic susceptibility increases markedly downcore in the uppermost $15 \mathrm{~cm}$ of the unit, but decreases slightly further downcore. Few shell fragments and minor bioturbation were observed in the core.

Core JM97-938. Core JM97-938 was recovered from about $500 \mathrm{~m}$ beyond the lobe margin in Tempelfjorden (Figs. 2b, 3b, Table 1). The core is $415 \mathrm{~cm}$ long and comprises two lithological units, 938-1 and 938-2 (Fig. 5b). Unit 938-1 (0-215 cm) comprises ca. 130 sub-horizontal couplets of reddish brown and dark to very dark greyish brown clayey silt with scattered clasts. The physical properties are similar to unit 937-1. The boundary between units 938-1 and 938-2 is gradational and characterized by darker sediment, more black mottles and less stratification in the lower unit. Furthermore, undrained shear strength and magnetic susceptibility are higher in unit 938-2.

Unit 938-2 (215-415 cm) comprises clayey silt, with clasts present in the uppermost $25 \mathrm{~cm}$ (Fig. 5b). The sediments are predominantly massive and have a dark to very dark greyish brown colour. However, some more reddish brown strata 
Fig. 2. (a) Map of the inner part of Tempelfjorden showing the distribution of the ice-marginal deposits and earlier documented glacier frontal positions (in years AD). (b) Isopach map of the icemarginal deposits, with locations of seismic lines and core sites. Profiles shown in Figs. 3 and 4 are marked with bold lines.
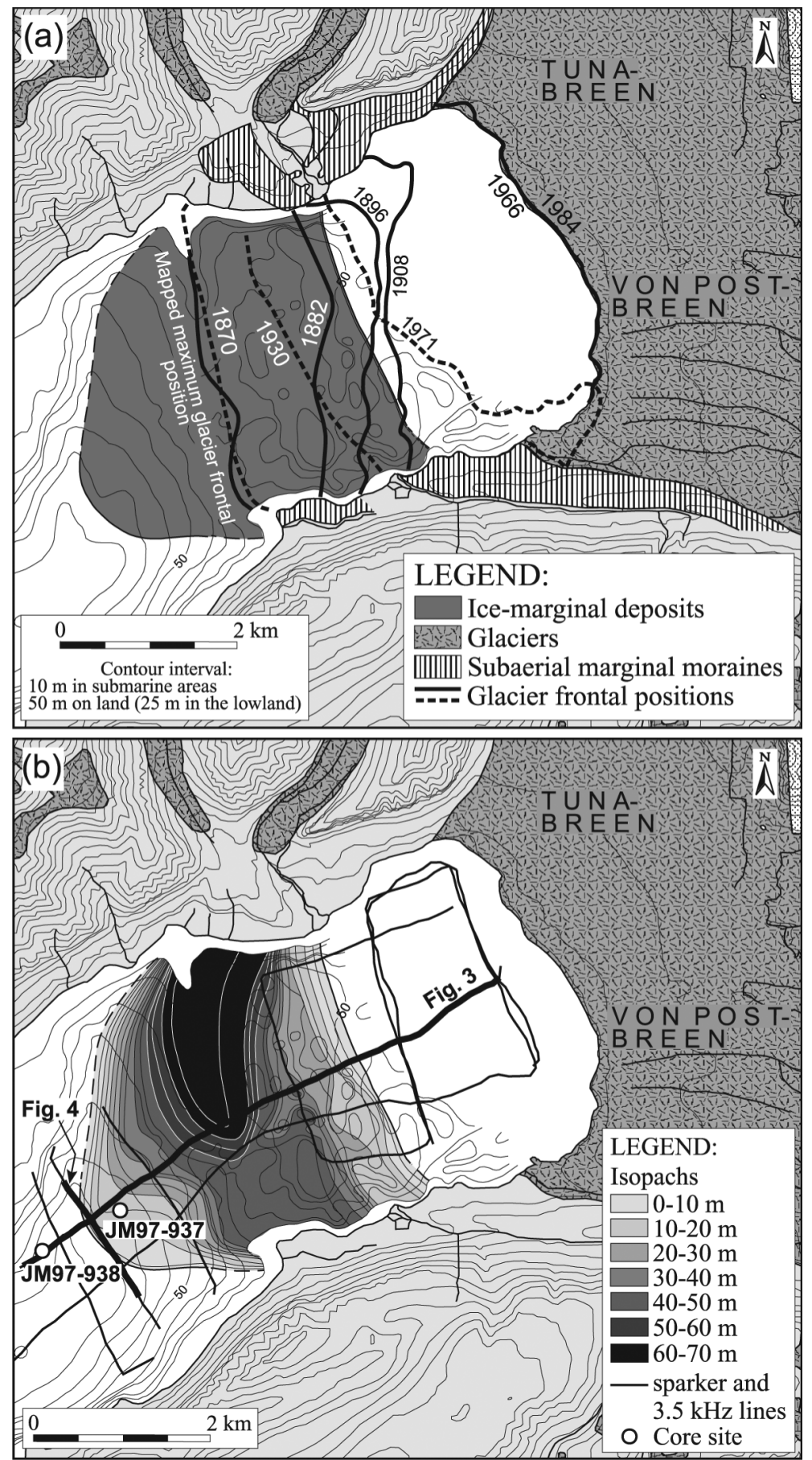

less than $3 \mathrm{~cm}$ thick occur. Boundaries between the differently coloured strata are predominantly gradational. From the top of the unit to its base, the amount of black mottles increases, while the proportion of more reddish strata decreases. Undrained shear strength increases downcore, as a gradual continuation of unit 938-1. Water content and density remain more or less constant 


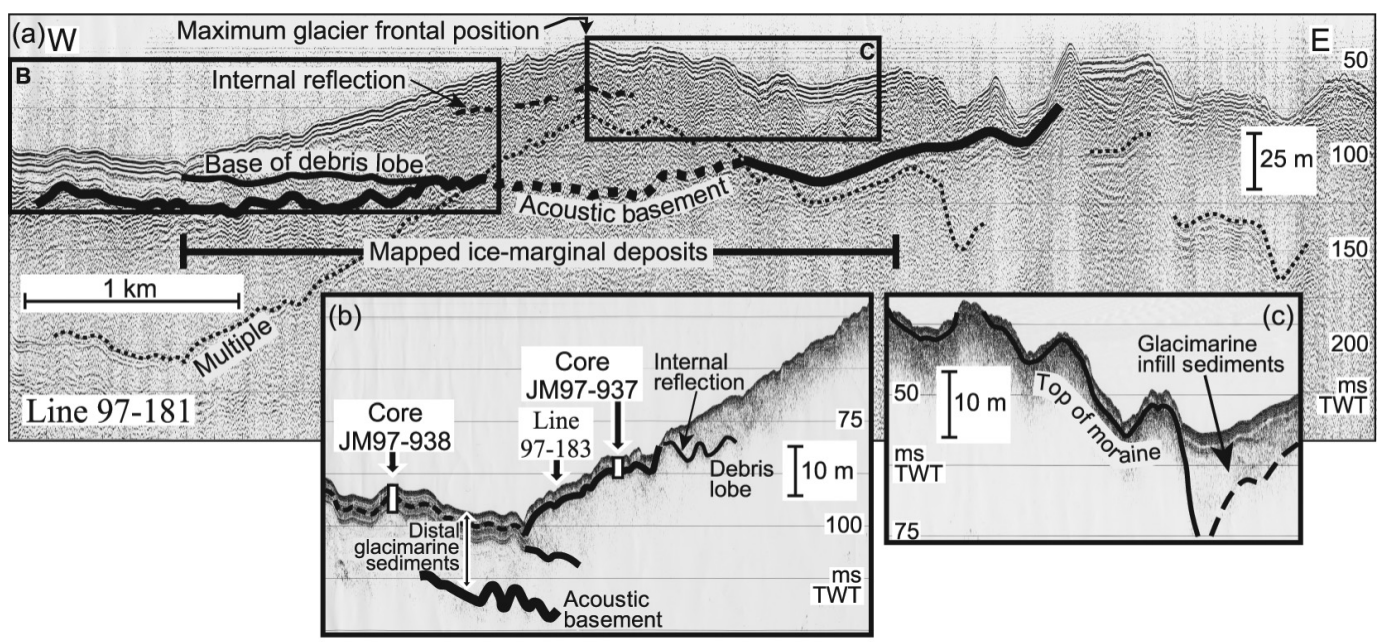

Fig. 3. (a) Sparker profile of the ice-marginal deposits in Tempelfjorden (for location, see Fig. 2b). (b) $3.5 \mathrm{kHz}$ profile of the debris lobe and the distal glacimarine sediments. Core sites and tie point to line 97-183 (see Fig. 4) are indicated. (c) $3.5 \mathrm{kHz}$ profile showing morainal ridges.

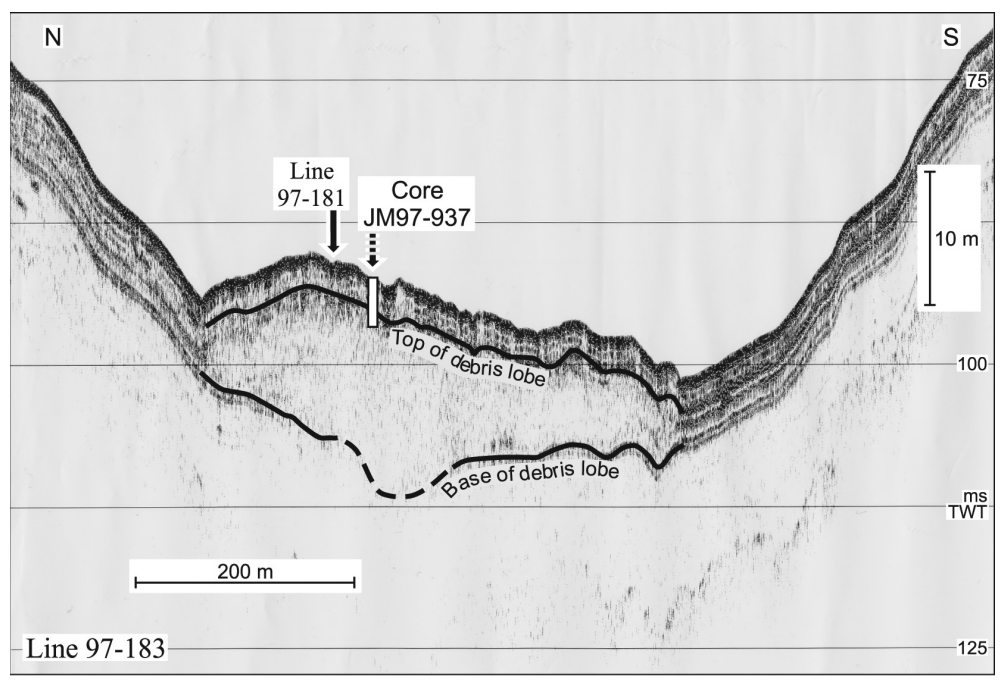

Fig. 4. $3.5 \mathrm{kHz}$ profile across the distal part of the debris lobe in Tempelfjorden (for location, see Fig. 2b). Tie point to line 97-181 and core site JM97-937, located about $300 \mathrm{~m}$ north-east of the profile, are indicated.

throughout the whole core. The magnetic susceptibility increases within the uppermost $40 \mathrm{~cm}$, and remains constant to the base. Few shell fragments and minor bioturbation were observed in the core.

Correlations. About $2.5 \mathrm{~m}$ of acoustically stratified sediments drape the debris lobe at core location JM97-937 (Figs. 3b, 4). Since unit 937-1 is $223 \mathrm{~cm}$ thick (Fig. 5a), it seems likely that it corresponds to the draping acoustically stratified sediments. Unit 937-2 is therefore inferred to be the top of the debris lobe. The draping acoustical- ly stratified sediments can be traced beyond the lobe to core site JM97-938, where their thickness exceeds $10 \mathrm{~m}$ (Fig. 3). The reflection that correlates with the base of the stratified sediments in core JM97-937 corresponds to the unit 938-1/9382 transition starting at $215 \mathrm{~cm}$ (Fig. 3b). Lithological marker horizons in units 937-1 and 938-1 provide exact correlation between the two cores.

Fig. 5 (opposite page). (a) Sediment core data, JM97-937. (b) Sediment core data, JM97-938. 


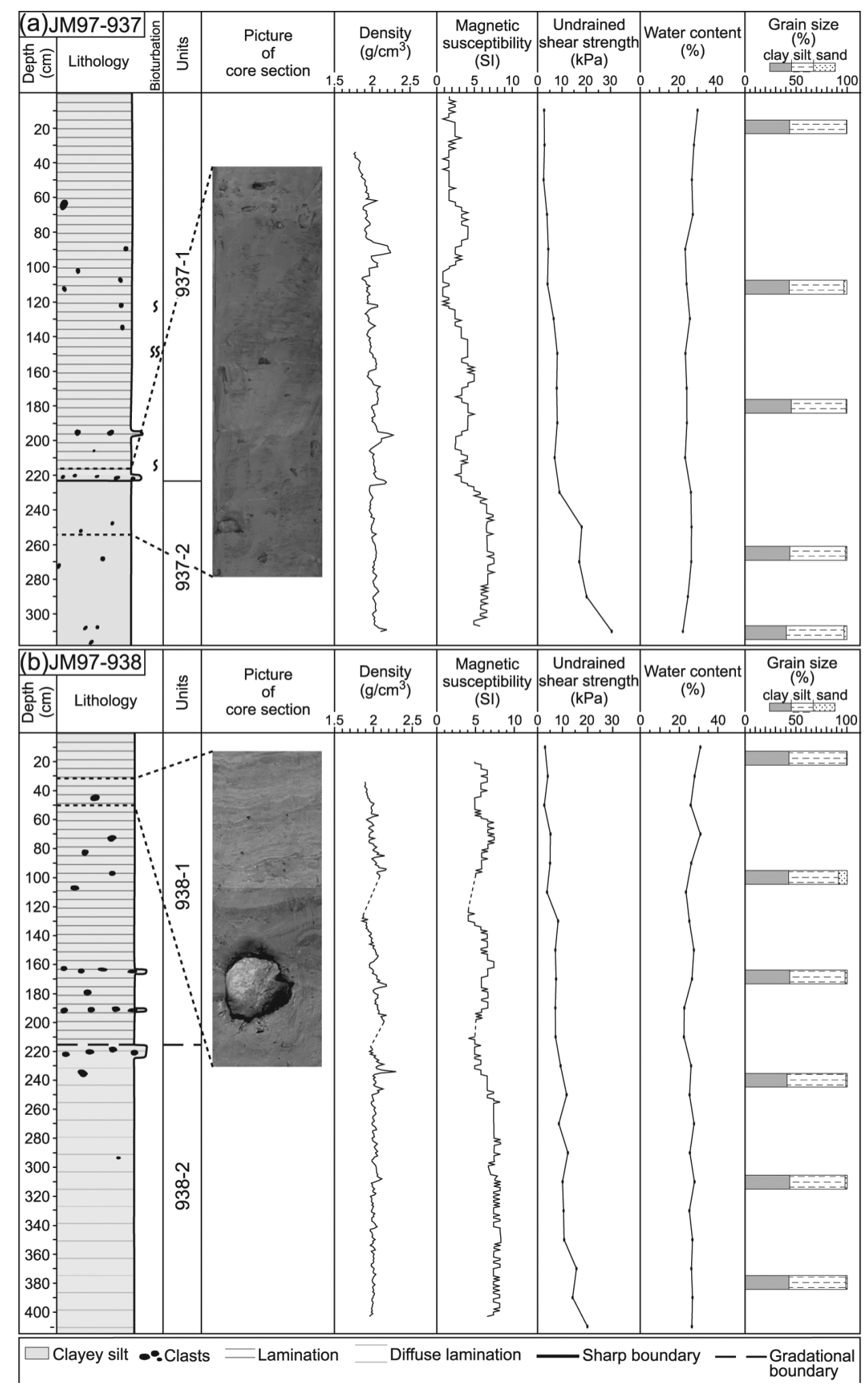

Plassen et al.: Polar Research 23(1), 89-110 
This indicates that the sedimentation rate at the core sites was similar following the deposition of the debris lobe. However, within the uppermost $50 \mathrm{~cm}$, the sedimentation rate at coring site JM97937 increased slightly.

The major sources of suspended sediments in Tempelfjorden are glacial meltwater streams debouching from Tunabreen and Von Postbreen at the fjord head, and the river Sassenelva at the southern side, close to the transition to Sassenfjorden (Fig. 1). Field observations show that the turbid overflow from Sassenelva has greyish brown colour, whereas the suspension off the glaciers is reddish brown, respectively (see also Korsun \& Hald 2000). The river De Geerelva, located about $15 \mathrm{~km}$ west of Sassenelva (Fig. 1), has its runoff period from June to September/ October (H. Benjaminsen, pers. comm.). It is inferred that the active time of Sassenelva does not differ significantly from this time window. The seasonal sea ice in Tempelfjorden melts in June, but exceptions occur. In some years new sea ice has not formed before the end of November (Korsun \& Hald 2000).

Because of the freezing of Sassenelva, sediment input to the fjord was limited to Tunabreen and Von Postbreen during most of the winters subsequent to the Neoglacial maximum. During the ice-free summer season, water masses from Sassenelva enter the fjord as surface sediment plumes. It is inferred that the greyish brown strata in the cores JM97-937 and JM97-938 were deposited during summer months, when both Sassenelva and Tempelfjorden were ice-free, while the reddish brown strata were deposited during winter. We defined one reddish brown and one greyish brown strata as one couplet.

In the glacimarine environment, rhythmical deposits in the form of varves or tidal rhythmites have been described (e.g. Elverhøi et al. 1980; Mackiewicz et al. 1984; Powell \& Molnia 1989; Cowan et al. 1997; Cowan et al. 1999; Gilbert et al. 2002; Gilbert 2003). Rhythmically laminated muds are generally deposited within a few kilometres to the ice margin, in ice-proximal settings (Ó Cofaigh \& Dowdeswell 2001). The core sites in Tempelfjorden are located $1 \mathrm{~km}$ and $2 \mathrm{~km}$ beyond the Neoglacial terminal moraine (Fig. 3), i.e. outside the present ice-proximal basin, and more than $10 \mathrm{~km}$ from the mouth of the river Sassenelva. Boundaries between couplets are predominantly gradational, indicating that deposition occurs through "passive process- es" (see Ó Cofaigh \& Dowdeswell 2001), i.e. by settling from suspension. Because no hiatus was observed, it is reasonable to assume that sedimentation at the coring sites was continuous. Furthermore, the grain size compositions of the matrixes in the greyish brown and reddish brown strata are almost identical in both cores.

Based on our observations, and the fact that water circulation in Tempelfjorden is relatively slow and surface water movement is predominantly wind-driven (F. Nilsen, pers. comm.), we suggest that colour changes are caused by slow seasonal variations, rather than rapid tidal changes. The glacier Von Postbreen reached its maximum Neoglacial position during the surge in 1870 AD (Hagen et al. 1993; Fig. 2). Because core JM97-937 comprises about 130 couplets, we suggest that the debris lobe was deposited during this surge. Thus, we infer that the stratified sediments in the cores are glacimarine varves (see Gilbert 2003) and not tidal couplets.

Assuming that the couplets are annual deposits, an average sedimentation rate of $17 \mathrm{~mm} / \mathrm{yr}$ for the last 130 years is estimated. This corresponds well with sedimentation rates of $10-20 \mathrm{~mm} / \mathrm{yr}$ in Van Mijenfjorden, southern Svalbard, for the last 200 - 400 years (Elverhøi et al. 1983).

\section{Billefjorden}

Nordenskiöldbreen, terminating in Adolfbukta, is the only tidewater glacier in Billefjorden (Figs. 1, $6 a)$. No surges have been recorded for this glacier. The crest of the ice-marginal deposits mapped in this study corresponds well to the 1896 AD and 1908 AD glacier frontal positions (De Geer 1910), and to the location of the subaerial marginal moraine (Figs. 6a, 7a). It is therefore inferred to be the terminal moraine deposited during the Neoglacial maximum around 1900 AD.

The ice-marginal deposits in Billefjorden, extending about $3 \mathrm{~km}$ beyond the present glacier front, have a minimum volume of $0.12 \mathrm{~km}^{3}$ (Fig. 6b, Table 2). The Neoglacial terminal moraine mimics the bedrock topography (Fig. 7a). The sea floor proximal of the terminal moraine is hummocky and has a sediment thickness of up to $65 \mathrm{~m}$.

A break in slope marks the transition from the terminal moraine to the distal basin with one debris lobe (Fig. 7a). A series of curved slip surfaces, evident on the sea floor as irregular topography, occur on the upper part of the debris lobe (Fig. 7a). The debris lobe has a thickness up to 
Fig. 6. (a) Map of Adolfbukta (inner Billefjorden) showing the distribution of the ice-marginal deposits and previously documented glacier frontal position (in years AD). (b) Isopach map of the ice-marginal deposits, with location of seismic lines. The profile shown in Fig. 7 is marked with a bold line.
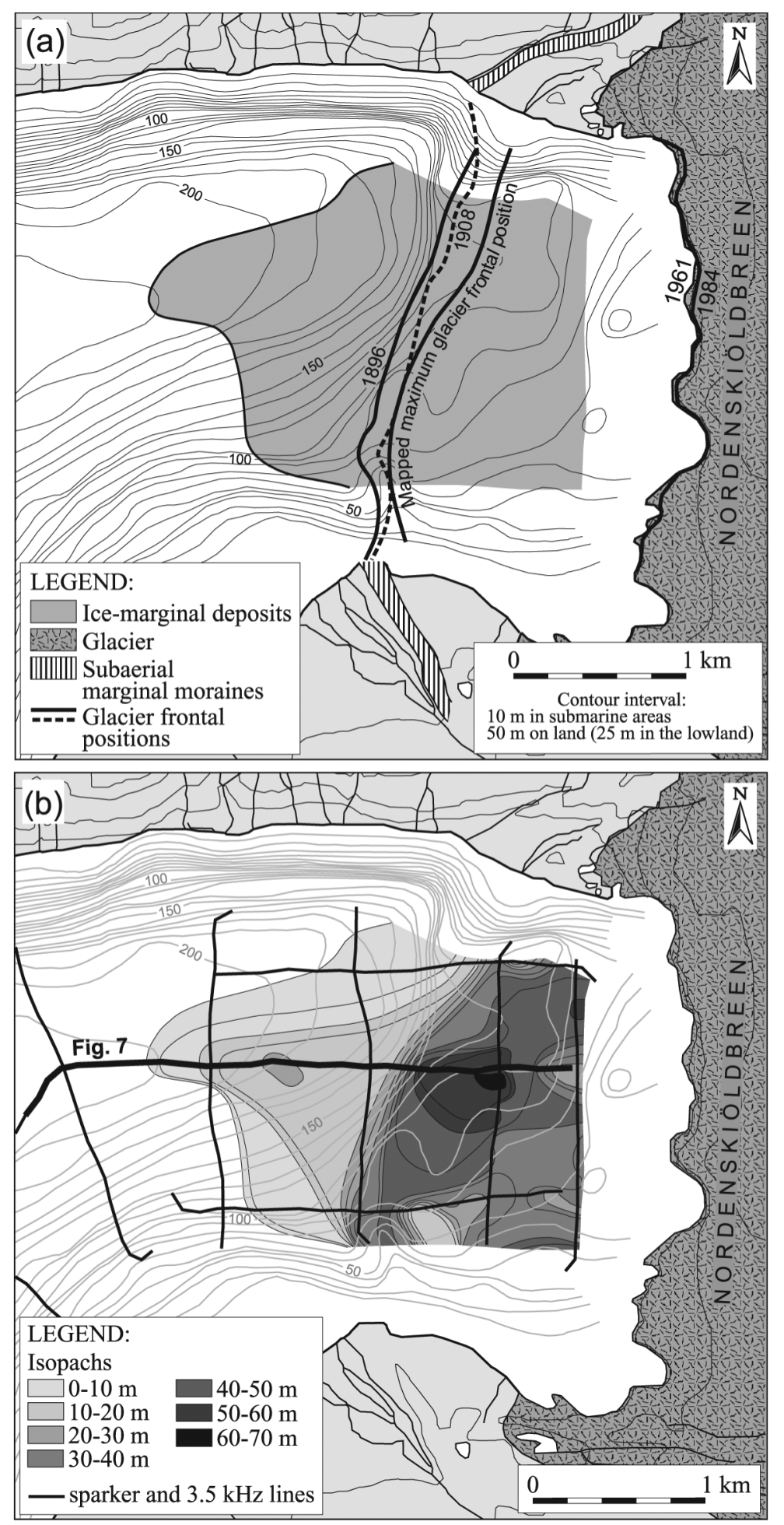


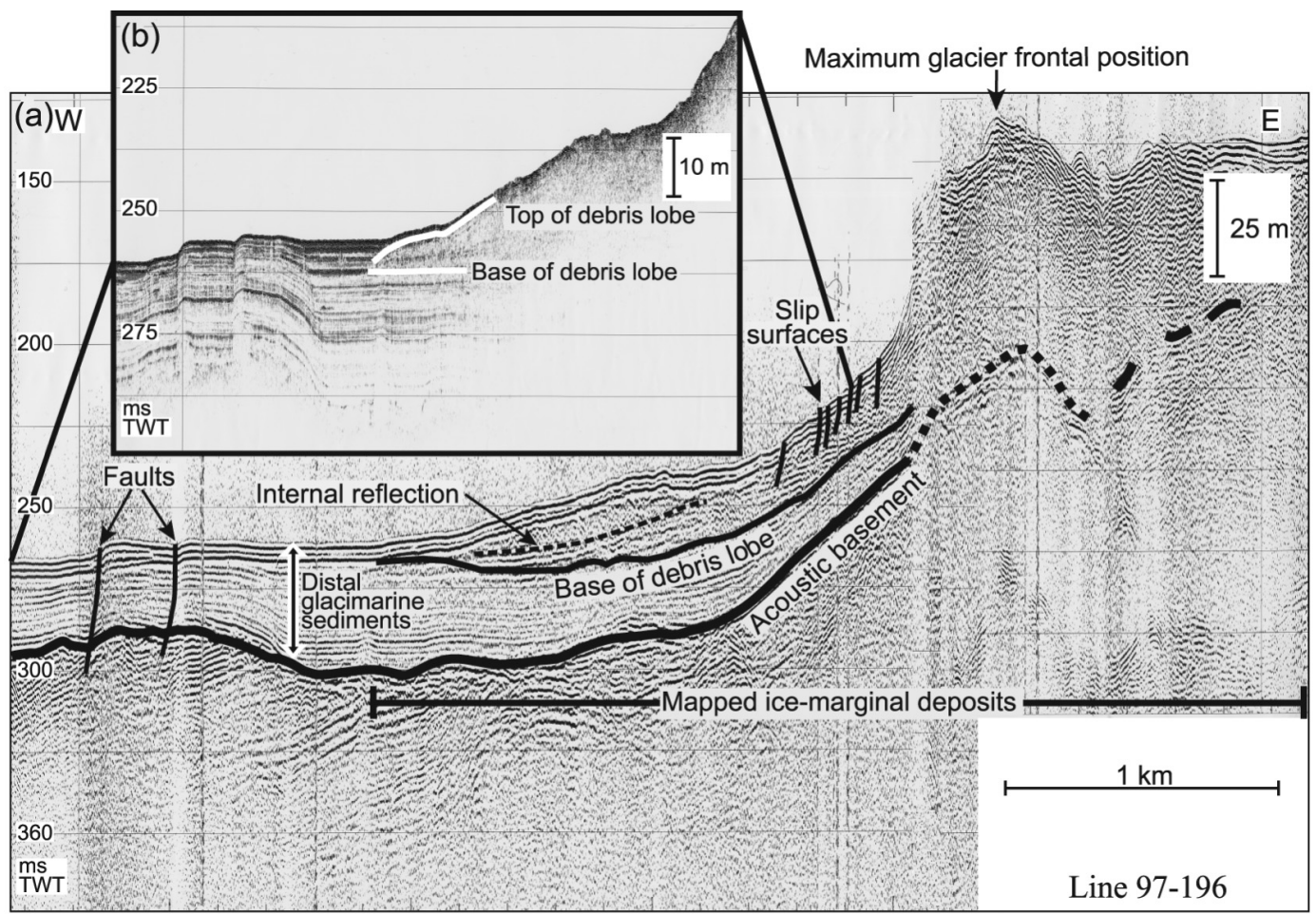

Fig. 7. (a) Sparker profile of the ice-marginal deposits in Adolfbukta, Billefjorden (for location, see Fig. 6b). Slip surfaces and faults are indicated. (b) $3.5 \mathrm{kHz}$ profile of the debris lobe and the distal glacimarine sediments.

$25 \mathrm{~m}$ in the central part (Fig. 6b). An internal reflection suggests a subdivision of the debris lobe (Fig. 7a). Less than $2 \mathrm{~m}$ of acoustically stratified glacimarine sediments overlie the distal part of the debris lobe (Fig. 7b). No sediment cover is detected on the proximal part. The irregular surface and the lack of a detectable sediment cover may indicate that the proximal part of the debris lobe comprises a recent slide.

\section{Yoldiabukta}

Of the two tidewater glaciers calving into the bay Yoldiabukta (Figs. 1, 8a), Wahlenbergbreen had a recorded surge in $1908 \mathrm{AD}$ (Hagen et al. 1993). In 1896 AD, Sveabreen extended to the outer ridge, while the glacier front of Wahlenbergbreen was situated in the inner bay (De Geer 1910; Fig. 8a). Just after the 1908 surge of Wahlenbergbreen, both glaciers were at their maximum positions, located along submarine moraines which continue as subaerial lateral moraines. These moraines are inferred to be the terminal moraines, reflecting the Neoglacial maximum ice extent. Lobe- shaped sediment wedges extend $2-3 \mathrm{~km}$ beyond the terminal moraines (Fig. 8a).

In Yoldiabukta, two distinct debris lobe sets occur (Fig. 9). The lower lobe set has a minimum volume of $0.18 \mathrm{~km}^{3}$ (Fig. 8 b, Table 2). Its thickness exceeds $45 \mathrm{~m}$ in the inner part, and gradually decreases outwards. The upper boundary is irregular (Fig. 9). A distinct internal reflection is present in the lower lobe set (Fig. 10).

The upper lobe set has a minimum volume of $0.07 \mathrm{~km}^{3}$ (Fig. 8c, Table 2). In the southern part of the bay, its thickness is less than $10 \mathrm{~m}$, and it gradually thins towards the toe (Fig. 9). In the northern part of the bay, the thickness exceeds $25 \mathrm{~m}$ (Fig. 10). At the upper, northern part of the lobe set, the surface is relatively irregular (Fig.

Fig. 8 (opposite page). (a) Map of Yoldiabukta showing the distribution of the debris lobes and previously documented glacier frontal positions (in years AD). (b) Isopach map of the lower debris lobe set, with location of acoustic lines and core site. (c) Isopach map of the upper debris lobe set, with location of acoustic lines and core site. Profiles shown in Figs. 9, 10 and 11 are marked with bold lines. 


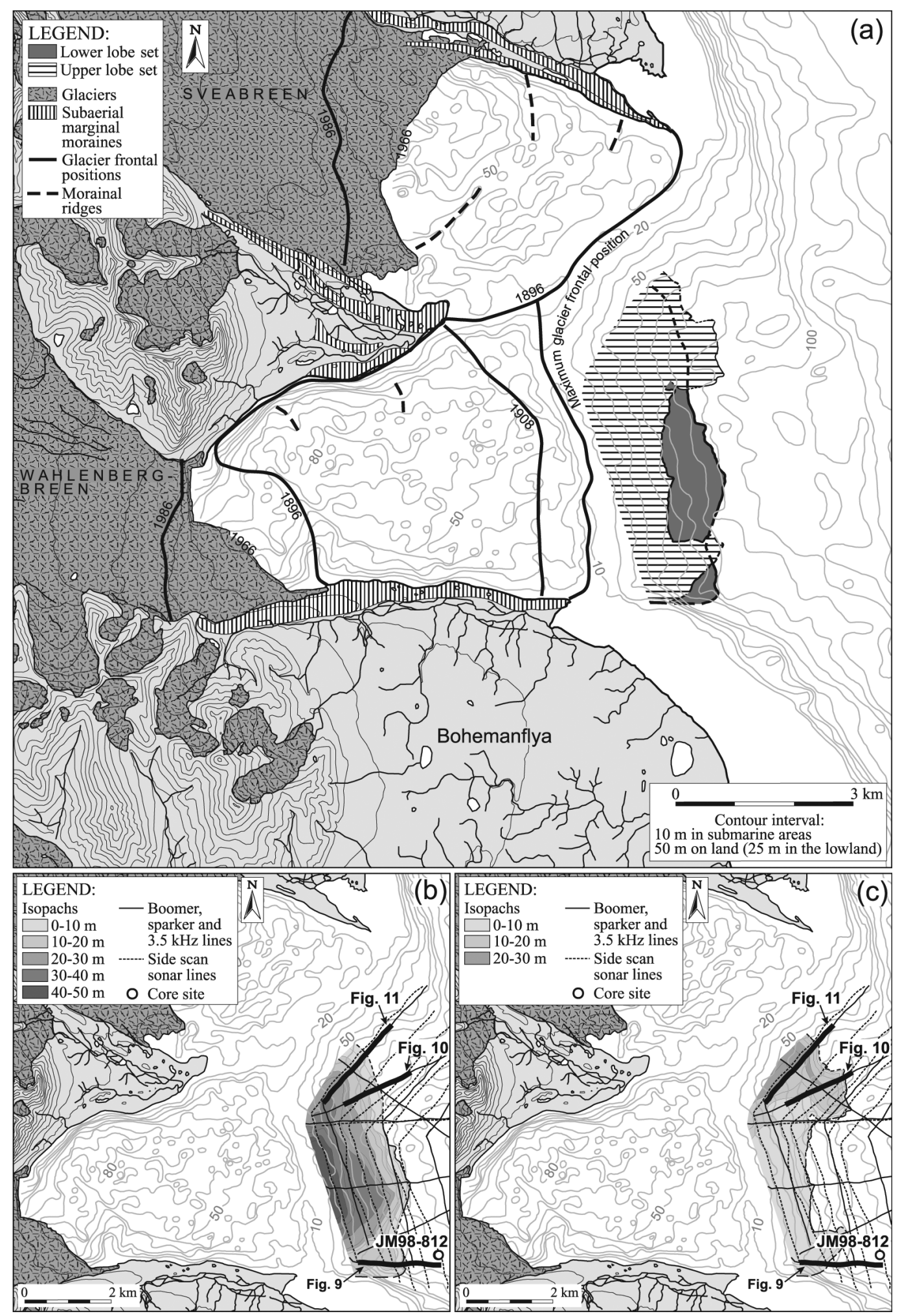

Plassen et al.: Polar Research 23(1), 89-110 


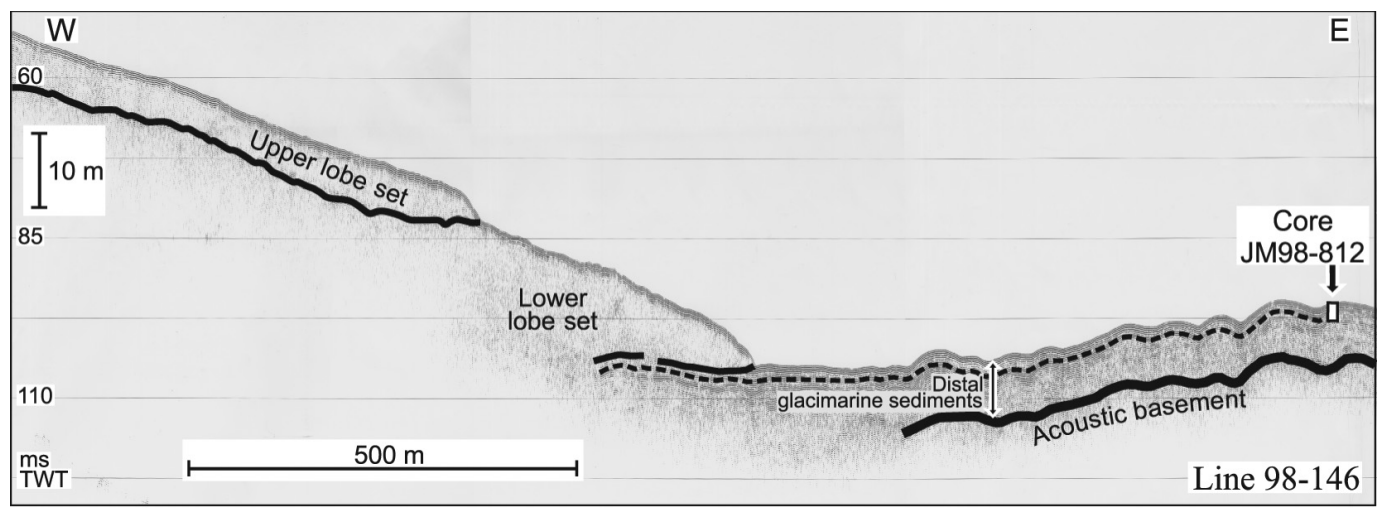

Fig. 9. $3.5 \mathrm{kHz}$ profile along the debris lobe sets in Yoldiabukta (for location, see Fig. 8b-c). Note the acoustically stratified sediments that can be followed beneath the lower lobe set.

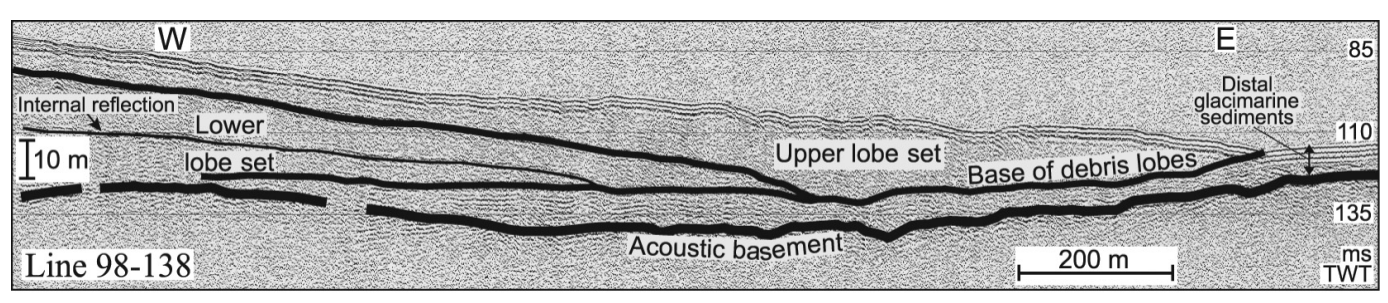

Fig. 10. Boomer profile of the debris lobe sets in Yoldiabukta (for location, see Fig. 8b-c). Note the internal reflection in the lower lobe set.

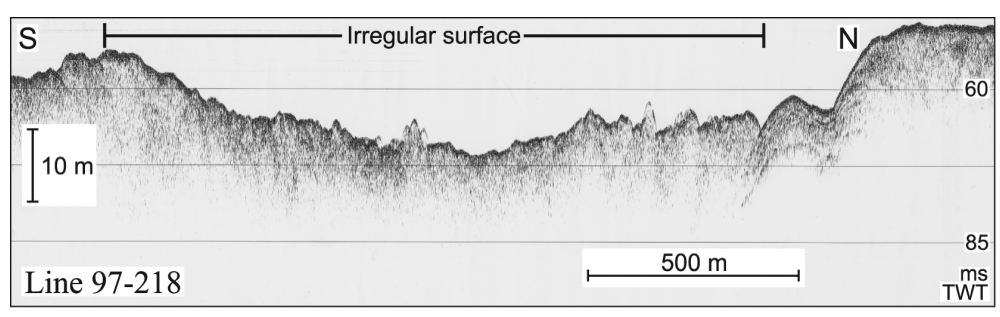

Fig. 11. $3.5 \mathrm{kHz}$ profile across the proximal part of the debris lobe sets in Yoldiabukta (for location, see Fig. 8b-c). Note the irregular surface.

11). There is no indication of sediments deposited from suspension over either the lower or the upper lobe set in Yoldiabukta (Fig. 9).

On side-scan sonar data, surface structures on upper parts of the upper lobe set appear as small tongues, about $50 \mathrm{~m}$ wide. The "hummocks", up to $3.5 \mathrm{~m}$ high, seen on the $3.5 \mathrm{kHz}$ records (Fig. 11) are assumed to be these small tongues. Where side-scan sonar data cover the lobe margins, they show that the margins end in tongue forms (Fig. 8a).

The acoustically stratified sediments can be traced below the debris lobes (Fig. 9), where they appear thinner. This may be due to compaction.

Core JM98-812. Core JM98-812, $197 \mathrm{~cm}$ long, was recovered about $1 \mathrm{~km}$ beyond the lobe margin in Yoldiabukta (Fig. 8b-c, Table 1). The uppermost $155 \mathrm{~cm}$ (unit 812-1) are composed of very dark greyish clayey silt with clasts $>1 \mathrm{~mm}$ (Fig. 12). The clasts comprise predominantly sub-rounded to angular dark siltstone. Clast content varies throughout the unit. Within the zones $113-123 \mathrm{~cm}$, and $145-155 \mathrm{~cm}$, few clasts occur. Two paired shells of Macoma calcarea, sampled from $146.5 \mathrm{~cm}$, are dated to $2265 \pm 55{ }^{14} \mathrm{C}$ yra (radiocarbon years ago; TUa-2718), i.e. 2310 cal yra (calendar years ago). This gives an average sedimentation rate of $0.6 \mathrm{~mm} / \mathrm{yr}$ for the last ca. 2300 cal yr (calendar years). The lowermost $42 \mathrm{~cm}$ of the core (unit 812-2) comprise a very 
dark greyish brown diamicton (Fig. 12). Angular clasts of dark siltstone dominate. Shell fragments are scattered throughout the whole core. A reworked fragment of Mytilus edulis, at $181 \mathrm{~cm}$, is dated to $3520 \pm 60{ }^{14} \mathrm{C}$ yra (3830 cal yra; TUa2719).

Correlations. Core JM98-812 was recovered from draping acoustically stratified sediments which are 7-8 m thick. This sediment package can be traced below the debris lobes (Fig. 9). The transition between units $812-1$ and $812-2$, at $155 \mathrm{~cm}$, just predates $2300 \mathrm{cal}$ yra (Fig. 12). This core level represents a reflection about $1 \mathrm{~m}$ below the base of the debris lobes. Thus, both the lower and upper debris lobe set must have been deposited well after $2300 \mathrm{cal}$ yra.

It seems reasonable that both lobe sets were deposited around $1900 \mathrm{AD}$, when the glacier fronts were located at the terminal moraine (Fig. 8a). The isopach map for the upper lobe set (Fig. $8 \mathrm{c}$ ) indicates that its northern part was deposited from Sveabreen. However, since Sveabreen reached its maximum position before Wahlenbergbreen (De Geer 1910; Fig. 8a), it is supposed that

Table 2. Geometrical and sedimentological data of the mapped ice-marginal deposits.

\begin{tabular}{|c|c|c|c|c|}
\hline & Tempelfjorden & Billefjorden & Yoldiabukta & Borebukta \\
\hline Size of inlet & $\begin{array}{l}4 \mathrm{~km} \text { wide, } \\
14 \mathrm{~km} \text { long }\end{array}$ & $\begin{array}{l}6 \mathrm{~km} \text { wide, } \\
30 \mathrm{~km} \text { long }\end{array}$ & $9 \mathrm{~km}$ wide & $\begin{array}{l}6 \mathrm{~km} \text { wide (inner), } \\
9 \mathrm{~km} \text { wide (outer) }\end{array}$ \\
\hline Max. water depth & $100 \mathrm{~m}$ & $210 \mathrm{~m}$ & $100 \mathrm{~m}$ & $150 \mathrm{~m}$ \\
\hline $\begin{array}{l}\text { Number of proximal } \\
\text { basins and glacier fronts }\end{array}$ & One & One & Two & Two \\
\hline \multicolumn{5}{|l|}{ Proximal basins } \\
\hline Approximate size & $15 \mathrm{~km}^{2}$ & $4 \mathrm{~km}^{2}$ & $\begin{array}{l}15 \mathrm{~km}^{2} \text { (northern), } \\
20 \mathrm{~km}^{2} \text { (southern) }\end{array}$ & $\begin{array}{l}30 \mathrm{~km}^{2} \text { (northern), } \\
8 \mathrm{~km}^{2} \text { (southern) }\end{array}$ \\
\hline Max. water depth & $55 \mathrm{~m}$ & $100 \mathrm{~m}$ & $\begin{array}{l}80 \mathrm{~m} \text { (northern), } \\
80 \mathrm{~m} \text { (southern) }\end{array}$ & $\begin{array}{l}70 \mathrm{~m} \text { (northern), } \\
50 \mathrm{~m} \text { (southern) }\end{array}$ \\
\hline Shape & Subhorizontal & $\begin{array}{l}\text { Sloping off the } \\
\text { glacier front }\end{array}$ & $\begin{array}{l}\text { Sloping towards the } \\
\text { glacier front }\end{array}$ & Synform \\
\hline \multicolumn{5}{|l|}{ Ice-marginal deposits } \\
\hline Area & $9.92 \mathrm{~km}^{2}$ & $4.45 \mathrm{~km}^{2}$ & No data & No data \\
\hline Volume & $0.32 \mathrm{~km}^{3}$ & $0.12 \mathrm{~km}^{3}$ & No data & No data \\
\hline Moraine: max. thickness & $70 \mathrm{~m}$ & $65 \mathrm{~m}$ & No data & No data \\
\hline \multicolumn{5}{|l|}{ Debris lobes } \\
\hline Number & One & One & Two & Two \\
\hline Area & $4 \mathrm{~km}^{2}$ & $2 \mathrm{~km}^{2}$ & $\begin{array}{l}7.96 \mathrm{~km}^{2} \text { (lower lobe } \\
\text { set), } 6.78 \mathrm{~km}^{2} \text { (upper } \\
\text { lobe set) }\end{array}$ & $\begin{array}{l}2.85 \mathrm{~km}^{2} \text { (lower lobe } \\
\text { set), } 6.34 \mathrm{~km}^{2} \text { (upper } \\
\text { lobe set) }\end{array}$ \\
\hline Volume & Ca. $0.15 \mathrm{~km}^{3}$ & Ca. $0.03 \mathrm{~km}^{3}$ & $\begin{array}{l}0.18 \mathrm{~km}^{3} \text { (lower lobe } \\
\text { set), } 0.07 \mathrm{~km}^{3} \text { (upper } \\
\text { lobe set) }\end{array}$ & $\begin{array}{l}0.03 \mathrm{~km}^{3} \text { (lower lobe } \\
\text { set), } 0.07 \mathrm{~km}^{3} \text { (upper } \\
\text { lobe set), }\end{array}$ \\
\hline Max. length & $2 \mathrm{~km}$ & $1.5 \mathrm{~km}$ & $3 \mathrm{~km}$ & $2.5 \mathrm{~km}$ \\
\hline Max. thickness & $50 \mathrm{~m}$ & $25 \mathrm{~m}$ & $\begin{array}{l}45 \mathrm{~m} \text { (lower lobe set), } \\
25 \mathrm{~m} \text { (upper lobe set) }\end{array}$ & $\begin{array}{l}15 \mathrm{~m} \text { (lower lobe set), } \\
25 \mathrm{~m} \text { (upper lobe set) }\end{array}$ \\
\hline Sediment composition & $\begin{array}{l}\text { Slightly deformed and } \\
\text { massive clayey silt with } \\
\text { scattered clasts }\end{array}$ & No data & No data & $\begin{array}{l}\text { Massive clayey silt } \\
\text { with abundant clasts }\end{array}$ \\
\hline \multicolumn{5}{|l|}{$\begin{array}{l}\text { Distal acoustically } \\
\text { laminated sediments }\end{array}$} \\
\hline Composition & $\begin{array}{l}\text { Stratified clayey silt } \\
\text { with scattered clasts }\end{array}$ & No data & $\begin{array}{l}\text { Massive clayey silt } \\
\text { with abundant clasts }\end{array}$ & No data \\
\hline Sedimentation rate & $\begin{array}{l}17 \mathrm{~mm} / \mathrm{yr} \text { (last } \\
130 \text { years) }\end{array}$ & No data & $\begin{array}{l}0.6 \mathrm{~mm} / \mathrm{yr} \\
\text { (last } 2300 \mathrm{yr} \text { ) }\end{array}$ & No data \\
\hline Source & Glaciers and rivers & Glaciers and rivers & Glaciers & Glaciers \\
\hline $\begin{array}{l}\text { Sediment cover on debris } \\
\text { lobes }\end{array}$ & $2 \mathrm{~m}$ & $1-2 \mathrm{~m}$ & Not detectable & Not detectable \\
\hline
\end{tabular}




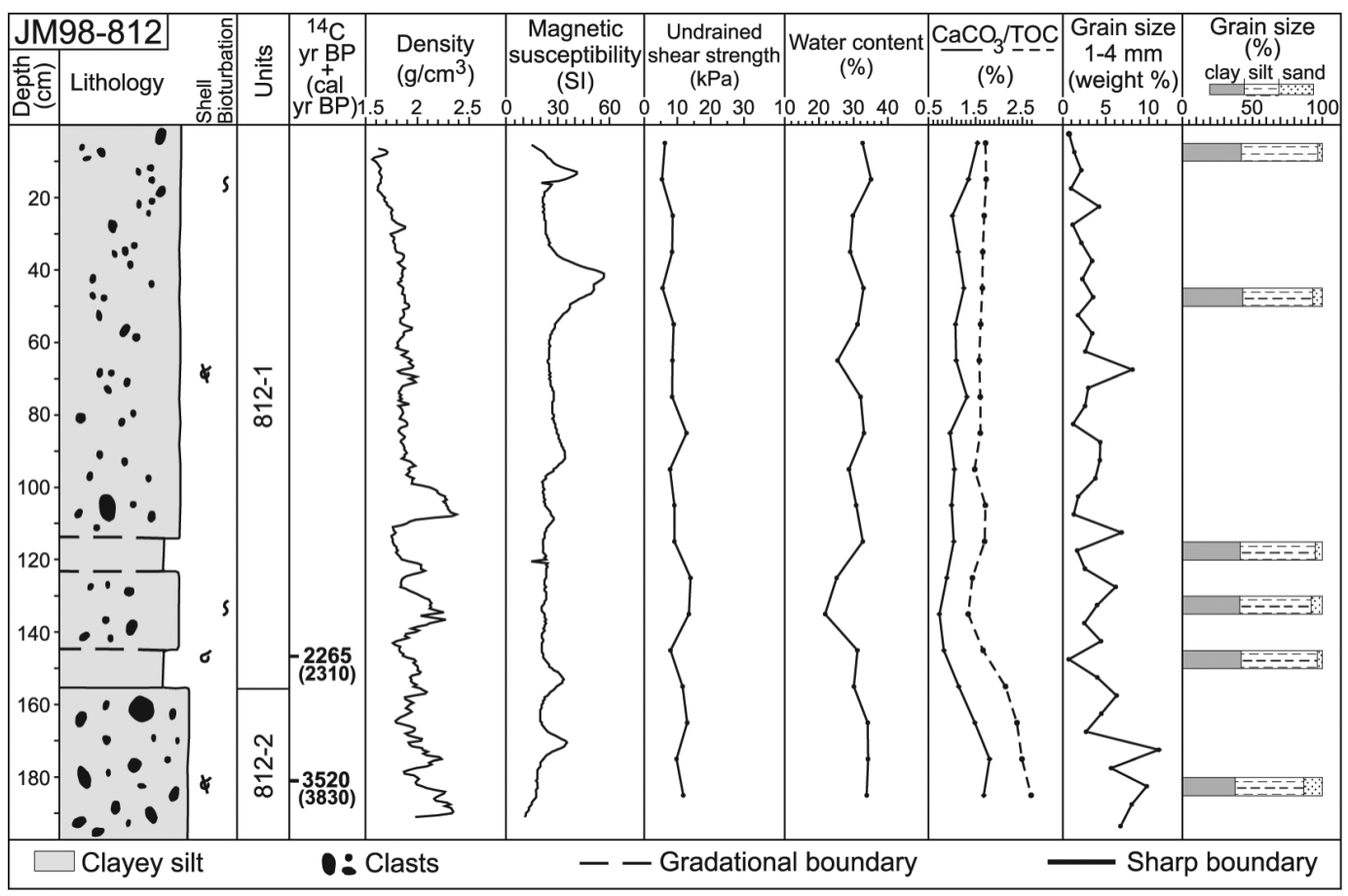

Fig. 12. Sediment core data, JM98-812. The relative sizes and abundances of clasts are derived from X-radiographs.

the northern part of the upper lobe set was deposited some time after Sveabreen reached its maximum position.

\section{Borebukta}

Two tidewater glaciers calve into the bay Borebukta: Borebreen in the north and Nansenbreen in the south (Figs. 1, 13a). The bathymetry and subaerial moraines indicate maximum Neoglacial glacier frontal positions at the outer ridge (Fig. 13a). Based on the mapping by De Geer (1910), this maximum is assumed to pre-date the 1910 position. A surge was recorded at Nansenbreen in 1947 AD (Liestøl 1969; Hagen et al. 1993). With a surge distance of only $2.5 \mathrm{~km}$ in 1947 (Liestøl 1969), it seems most likely that the terminal moraine in Borebukta was deposited before 1910 AD. Lobe-shaped sediment wedges extend about $2.5 \mathrm{~km}$ beyond the terminal moraine (Fig. 13a). A bedrock ridge separates the two lobe systems. Acoustically stratified sediments can be traced below the lobes (Fig. 14).

In Borebukta, an upper and lower debris lobe set can be distinguished, the upper lobe set covering the lower one entirely (Figs. 13, 14). The lower lobe set has a minimum volume of $0.03 \mathrm{~km}^{3}$ (Fig. 13b, Table 2) and maximum thickness of about $15 \mathrm{~m}$. The upper lobe set has a minimum volume of $0.07 \mathrm{~km}^{3}$ (Fig. 13c, Table 2). A thickness of up to $25 \mathrm{~m}$ is mapped in its inner western part. The upper part of the upper lobe set has a relatively irregular surface, compared with the lower part (Fig. 14). No deposits from suspension can be detected at the surface of the upper lobe set.

Side-scan sonar data reveal surface structures on the upper lobe set (Fig. 15). They appear mostly as short tongue-like features, transverse, undulating sub-parallel ridges and downslopeoriented lineations which are best expressed on the upper and middle parts of the lobe set. These surface structures are assumed to coincide with the hummocky relief of about $1.5 \mathrm{~m}$ seen on the north-western part of the $3.5 \mathrm{kHz}$ record (Fig. 14).

Fig. 13 (opposite page). (a) Map of Borebukta showing the distribution of the debris lobes and previously documented glacier frontal positions (in years AD). (b) Isopach map of the lower debris lobe set, with locations of acoustic lines and core site. (c) Isopach map of the upper debris lobe set, with locations of acoustic lines and core site. The profile shown in Fig. 14 is marked with a bold line. 


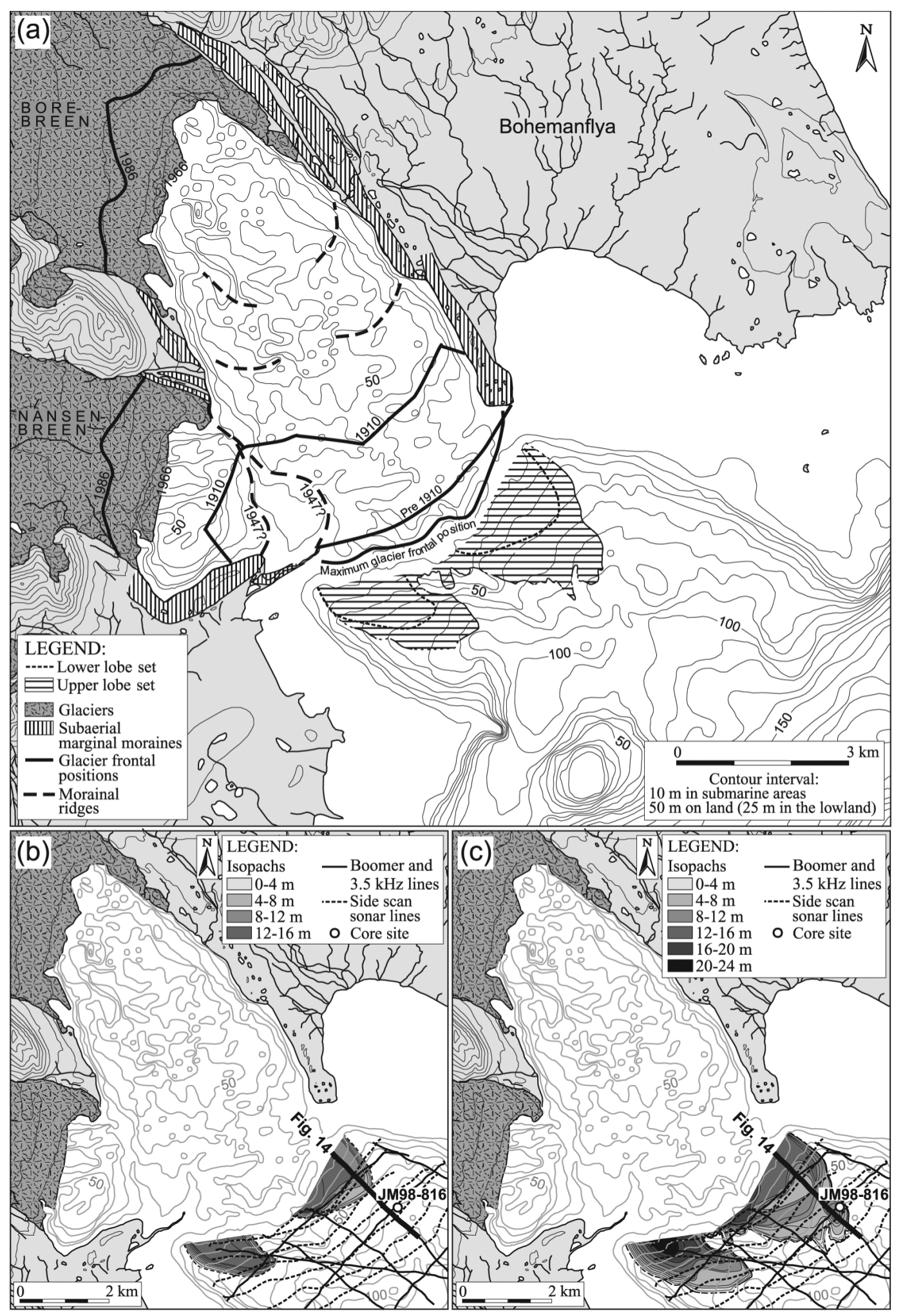

Plassen et al.: Polar Research 23(1), 89-110 


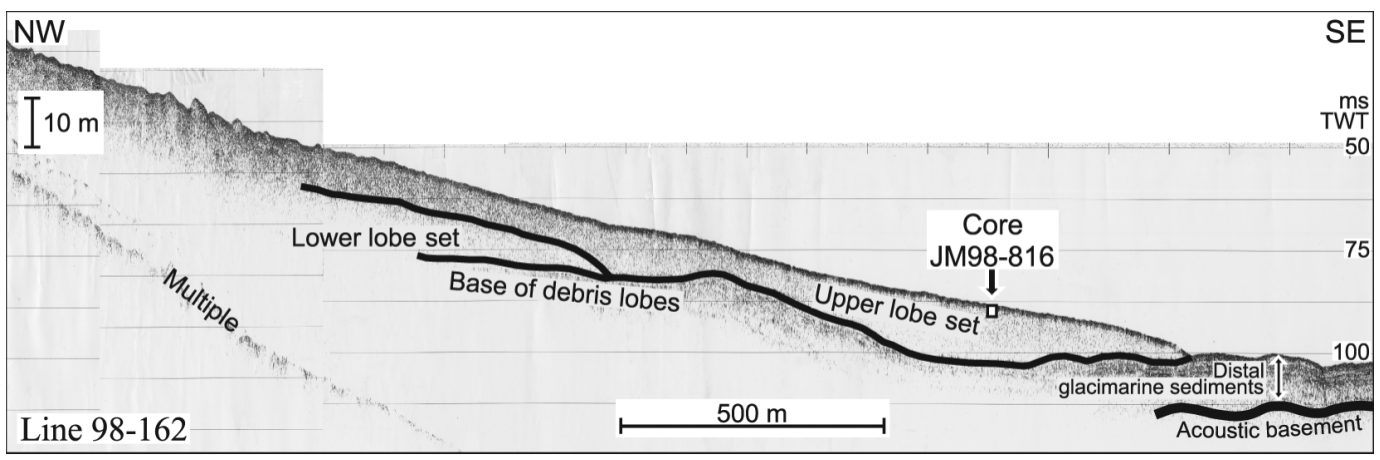

Fig. 14. $3.5 \mathrm{kHz}$ profile along the debris lobe sets in Borebukta (for location, see Fig. 13b-c). Core JM98-816 is about $150 \mathrm{~m}$ northeast of the position indicated on the profile.

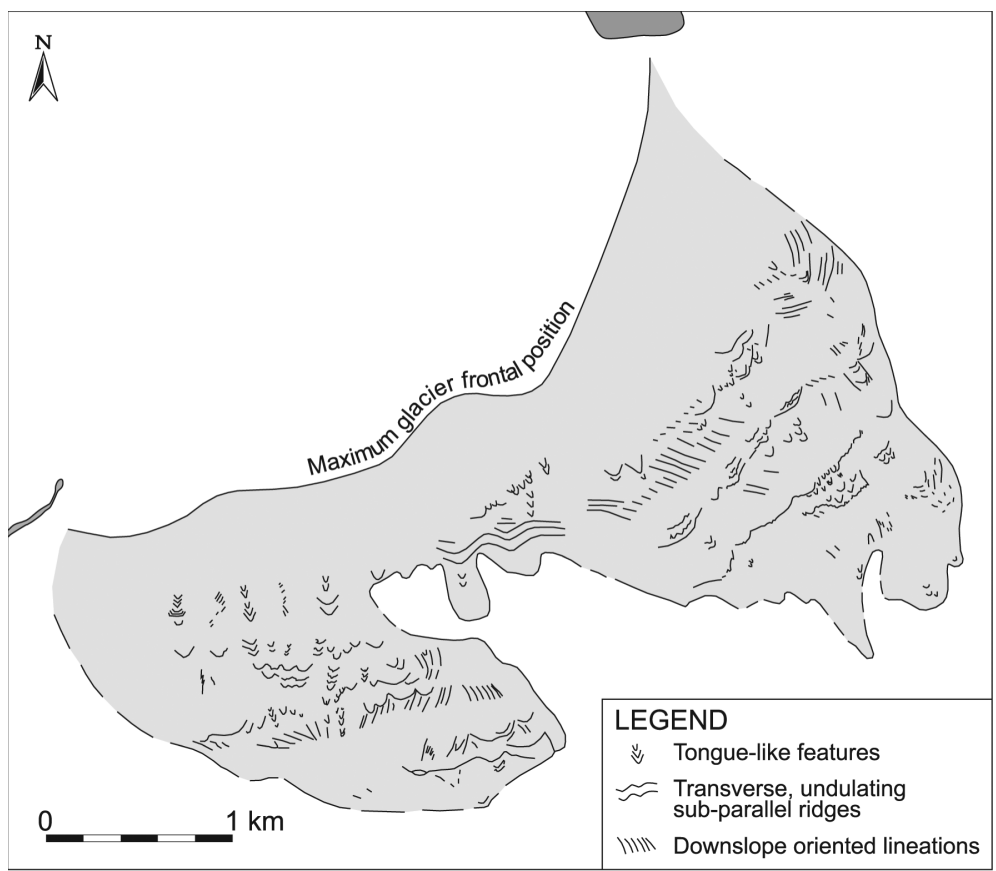

Fig. 15. Sketch of side-scan sonar records showing surface structures (tongue-like features, as well as transverse, undulating sub-parallel ridges and downslope oriented lineations) on the upper lobe set in Borebukta.

The average width across each tongue is about 50 $\mathrm{m}$ (Fig. 15). Sometimes tongues merge into transverse, undulating sub-parallel ridges. Where sidescan sonar data cover the lobe margins, they show that the margins also end in tongue forms.

Core JM98-816. Core JM98-816 was recovered from the upper lobe set in Borebukta (Fig. 13b-c, Table 1). The core is $200 \mathrm{~cm}$ long, and comprises very dark greyish brown clayey silt with subrounded to angular clasts of dark siltstone $>1 \mathrm{~mm}$ (Fig. 16). The density and number of clasts show a slightly increasing trend downcore. The low- ermost $5 \mathrm{~cm}$ comprise a larger number of clasts $>4 \mathrm{~mm}$. In addition, the undrained shear strength is highest close to the bottom of the core. The water content decreases slightly downcore. Shell fragments are scattered throughout the whole core.

Since core JM98-816 was recovered from the upper lobe set in Borebukta, about $300 \mathrm{~m}$ inside the lobe margin (Figs. 13c, 14), and no deposits from suspension are detected on the lobe surface, it is believed that core JM98-816 comprises the uppermost $2 \mathrm{~m}$ of the debris lobe. 


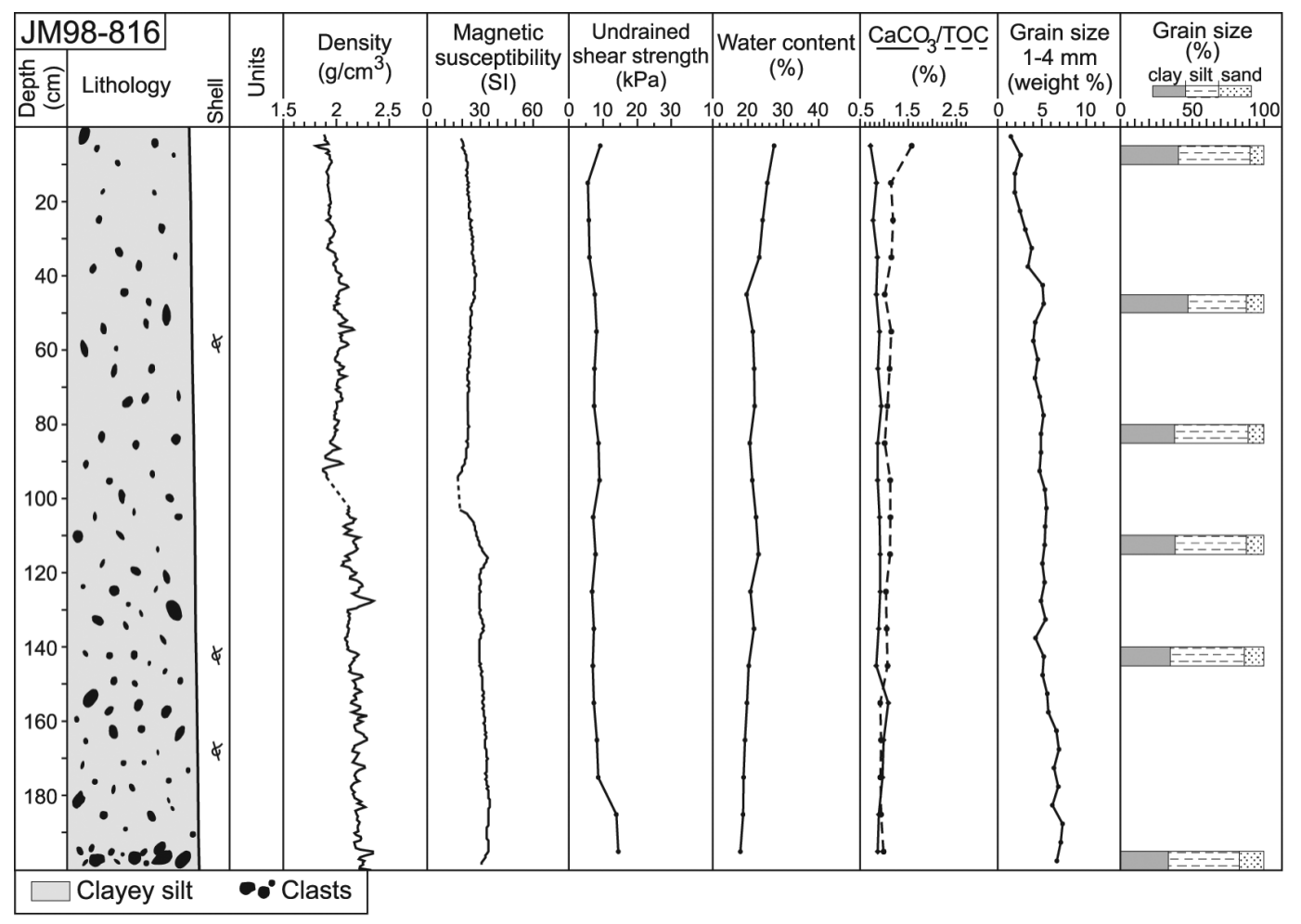

Fig. 16. Sediment core data, JM98-816. The relative sizes and abundances of clasts are derived from X-radiographs.

\section{Discussion}

\section{Moraines}

The seismic data from Tempelfjorden and Billefjorden document a Neoglacial terminal moraine, as well as morainal ridges and hummocky moraines in the proximal basins (Figs. 3a, 7a). On sparker profiles these moraines have a mainly chaotic signature (Mitchum et al. 1977), but some internal incoherent reflections can be identified. Such reflection patterns are often interpreted as “till” (e.g. Praeg et al. 1986; Vorren et al. 1989). On the $3.5 \mathrm{kHz}$ records, the moraines show lack of penetration (Fig. 3c). The hummocky surfaces of the moraines are covered with acoustically transparent/semi-transparent sediments, predominantly accumulated in depressions (Fig. 3c). These sediments are interpreted to be deposited from suspension after the glacier retreated from its maximum position.

In Tempelfjorden, morainal ridges occur behind the terminal moraines. Whittington et al. (1997) proposed similar ridges off Blomstrandbreen,
Kongsfjorden, to be annual retreat moraines. Moraine-mound complexes, as a result of thrusting, are characteristic features of the proglacial areas of land-terminating valley glaciers on Svalbard (Huddart \& Hambrey 1996; Hambrey et al. 1999; Glasser \& Hambrey 2001). The asymmetry of the morainal ridges in Tempelfjorden (Fig. 3c) may represent stacked thrust sheets, indicating that these ridges might be formed by thrusting, rather than pushing.

\section{Debris lobes}

On $3.5 \mathrm{kHz}$ profiles, the acoustic signature of the debris lobes is transparent and partly semi-transparent (Figs. 3, 4, 7, 9, 11, 14). The debris lobes have irregular proximal and smooth distal surfaces (Fig. 14). However, as seen in Fig. 15, surface structures also occur on their distal parts, but these have a relief that is too low to be expressed on the seismic data. Surface gradients are generally $1-2^{\circ}$, while the lobe margins are steeper. Side-scan sonar data from the debris lobes in Yoldiabukta and Borebukta show tongue-like 


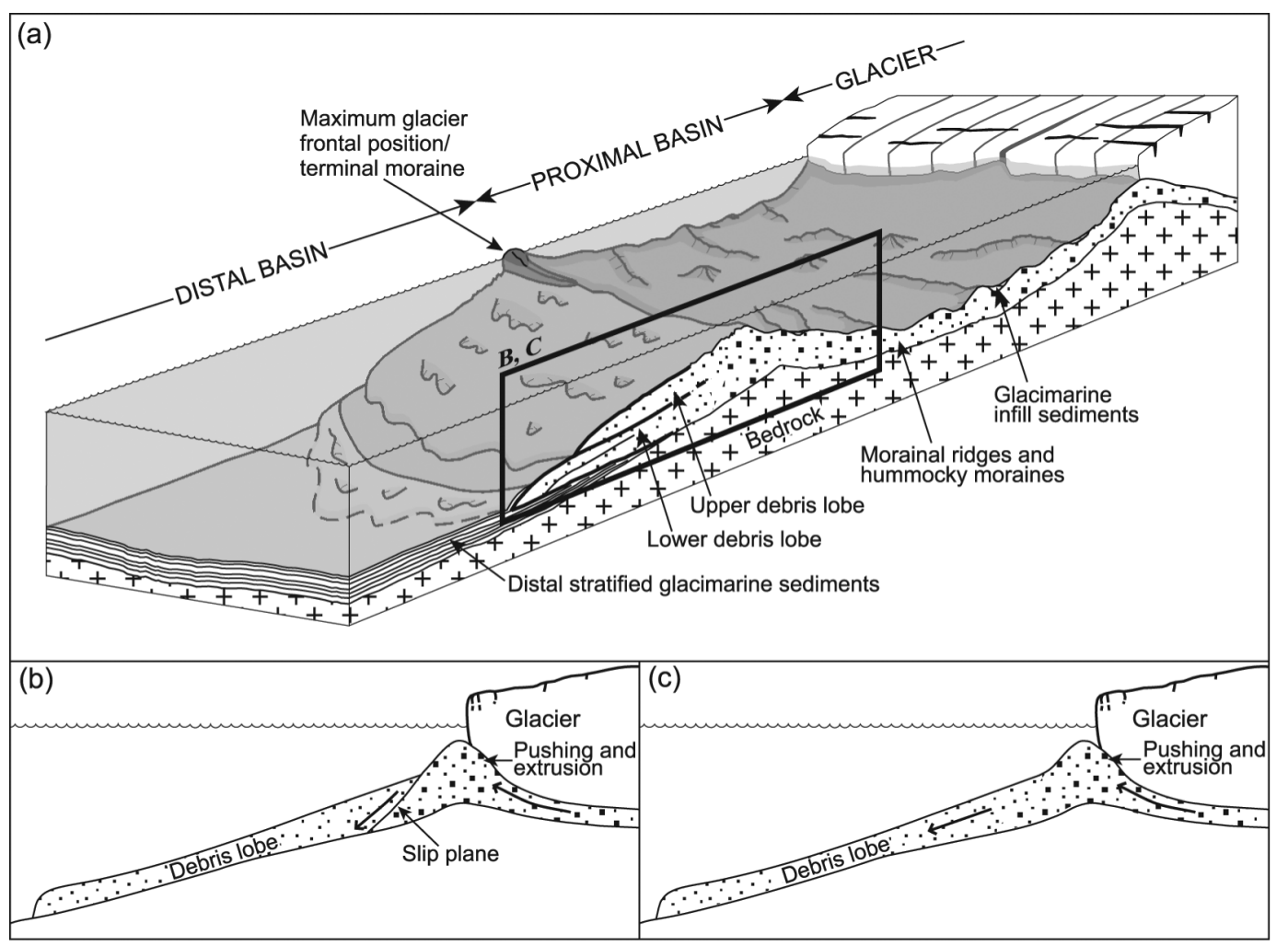

Fig. 17. (a) Diagram showing morphological elements and sediment packages of the mapped ice-marginal deposits. Two possibilities for debris lobe formation are suggested: (b) the deposition of the debris lobes occurs subsequently to the formation of the terminal moraines, or (c) synchronous formation of the terminal moraines and the debris lobes.

features, as well as transverse, undulating subparallel ridges and downslope-oriented lineations on the surface (Fig. 15). The tongue-like features may correspond to slumps with lobate margins, as observed on the distal flank of the surge moraine deposited from Bråsvellbreen (Solheim \& Pfirman 1985), as well as to lobate flow forms on the "till flows" in Ekmanfjorden (Boulton et al. 1996). They may also be analogues to the active flow lobes on the Kongsvegen lateral moraine (Bennett et al. 2000). The transverse, undulating sub-parallel ridges may be due to surface creep.

The lobe sediments in Borebukta comprise massive clayey silt with abundant clasts (Fig. 16). However, the lobe sediments in Tempelfjorden comprise predominantly massive clayey silt with scattered clasts (Fig. 5a). Intercalation of reddish brown strata within the lobe in Tempelfjorden is inferred to reflect reworked glacimarine mud. The lithological compositions thus indicate that the debris lobes comprise both glacigenic diamic- ton and reworked older glacimarine sediments. Deformation in the uppermost part of the lobe may indicate that it was transported downslope from pushed and extruded material from beneath the glacier, at the end of a glacier advance or surge, and during stagnation (see Boulton et al. 1996), rather than from subaqueous outwash sediments (Elverhøi et al. 1983).

The results from Tempelfjorden indicate that the debris lobe was deposited during the 1870 surge of Von Postbreen. In Yoldiabukta, it is apparent that both debris lobe sets were deposited around 1900 AD. Sediment wedges "mark" the terminal moraines deposited during the maximum glacier extent of the Neoglacial (Elverhøi et al. 1995). Based on this information, in addition to that concerning the location and timing of the maximum glacier frontal positions in Billefjorden and Borebukta, we infer that all the debris lobes investigated were deposited at the turn of the 20th century when the glacier fronts reached 
their maximum positions during the Neoglacial. The distinct division between two separate debris lobe sets in Yoldiabukta and Borebukta (Figs. 9, 14) probably marks two separate glacier advance or surge episodes. Internal reflections, identified in some of the debris lobes, probably indicate individual flows (Figs. 3b, 7a, 10). The absence of stratified sediments between the individual flows, as well as between lobe sets, indicates that deposition of the debris lobes occurred within a short time interval. Undisturbed acoustically stratified sediments below the debris lobes indicate no or little basal erosion during deposition.

\section{Distal acoustically stratified facies}

Beyond, and to some extent beneath and above the debris lobes, acoustically stratified draping sediments occur (Figs. 4, 7b, 9, 14). The thicknesses of these sediments vary from 10 to $20 \mathrm{~m}$ beyond the debris lobes in Tempelfjorden and Billefjorden, and from 7 to $8 \mathrm{~m}$ beyond the debris lobes in Yoldiabukta and Borebukta. These sediments are interpreted to be of distal glacimarine and marine origin, being deposited since the last deglaciation (Elverhøi et al. 1995).

In Tempelfjorden, these sediments comprise couplets of clayey silt with low clast content (Fig. 5b). Boundaries between couplets are predominantly gradational, indicating that deposition occurs through "passive processes" (see Ó Cofaigh \& Dowdeswell 2001), i.e. by settling from suspension. This implies that the main sediment transport in Tempelfjorden occurs in surface waters rather than in bottom currents, as proposed for Kongsfjorden by Elverhøi et al. (1983). The different colours of the sediments indicate two main sources, the river Sassenelva and the glaciers Von Postbreen and Tunabreen (Fig. 1c).

In Yoldiabukta, the distal acoustically stratified facies comprises massive clayey silt with abundant clasts (Fig. 12). The clasts are inferred to represent ice-rafted debris (IRD), derived from icebergs or sea ice. Since no major rivers drain into the bay, the clayey silt is assumed to be derived from glacial meltwater streams and icebergs.

The average sedimentation rate for the distal sediments in Tempelfjorden is $17 \mathrm{~mm} / \mathrm{yr}$ for the last 130 years. This coincides well with assumed accumulation rates of $10-20 \mathrm{~mm} / \mathrm{yr}$ in the inner basin of Van Mijenfjorden during the last 200 400 years (Elverhøi et al. 1983). In Yoldiabukta, the average sedimentation rate of $0.6 \mathrm{~mm} / \mathrm{yr}$ for the distal sediments during the last $2300 \mathrm{cal}$ yr is rather low compared with Tempelfjorden. However, it is equal to estimates from the central Isfjorden (Elverhøi et al. 1983). Higher sediment accumulation rates in Tempelfjorden, compared with Yoldiabukta, are explained by high sediment supply from rivers flowing into Tempelfjorden, in addition to the glaciers. This indicates that subaerial erosion has an important influence on sediment supply. The low proportion of clasts in the distal sediments in Tempelfjorden may indicate low frequency of iceberg calving compared with Yoldiabukta or, more likely, that higher accumulation of sediments deposited from suspension masks IRD in Tempelfjorden (see Elverhøi et al. 1980; Gilbert et al. 2002).

\section{Comparison with other submarine ice- marginal deposits}

The Tempelfjorden and Billefjorden, ice-marginal deposits are characterized by high-relief terminal moraines (Figs. 3a, 7a). Compared with other ice-marginal deposits on Svalbard, the system in Tempelfjorden best corresponds to the terminal moraine in front of Blomstrandbreen in Kongsfjorden (Whittington et al. 1997), as well as to the surge-moraine off Paulabreen in Van Mijenfjorden (Hald et al. 2001). In Billefjorden there is a steep slope, reflecting the bedrock topography, in front of the terminal moraine (Fig. 7a). The debris lobe is less extensive than at the other locations investigated. The system in Billefjorden has more similarity with the non-surging glacierfjord complex in Krossfjorden, north-west Spitsbergen, described by Sexton et al. (1992).

The lobe-shaped sediment wedges in Yoldiabukta (Fig. 9) and Borebukta (Fig. 14) have a morphology and acoustic signature comparable to the "till flows" in Ekmanfjorden, described by Boulton et al. (1996). Lack of data from the proximal areas in Yoldiabukta and Borebukta prevents a detailed comparison with the corresponding parts of these systems. Basins with irregular bathymetry extend from the terminal moraines to the present glacier fronts. Some morainal ridges seem to be present (Figs. 8a, 13a), but the generally irregular basin floors may correspond to surge zones (Solheim 1991) or zones of crevassefill ridges (Boulton et al. 1996).

The ice-marginal deposits of our study, as well as other ice-marginal deposits in Svalbard (Elverhøi et al. 1995; Boulton et al. 1996; Whittington 
et al. 1997; Hald et al. 2001), are characterized by lobe-shaped sediment wedges beyond a terminal moraine. The debris lobes in Tempelfjorden and Borebukta are composed of diamictons, as the sediment wedge in Ekmanfjorden (Boulton et al. 1996).

Ice-marginal deposits of temperate glaciers are characterized by ice-contact fans or deltas, in front of terminal moraines (Powell 1990; Lønne 1995; Lyså \& Vorren 1997). These deposits show stratification and foreset bedding, and they are mainly composed of coarse sediments. The differences in architecture and lithology, between the polythermal Svalbard and temperate ice-marginal deposits, show that temperate glaciers are influenced more strongly by meltwater-controlled sediment delivery than are polythermal glaciers.

\section{Conceptual model}

Based on morphological elements and their sedimentological composition, we propose a model for proglacial sedimentation by polythermal tidewater glaciers (Fig. 17, Table 2).

The four inlets investigated are characterized by proximal basins between the present glacier fronts and the Neoglacial terminal moraines from around 1900 AD (Fig. 17). Yoldiabukta and Borebukta have two separate glacier fronts and wider proximal basins compared with Tempelfjorden and Billefjorden. The proximal basins in Tempelfjorden and Billefjorden are characterized by morainal ridges and hummocky moraines, covered with glacimarine infill sediments.

The distal basins are characterized by debris lobes and stratified glacimarine sediments (Fig. 17). Yoldiabukta has the most extensive debris lobe system and Billefjorden has the smallest. In Yoldiabukta and Borebukta, the debris lobe deposits comprise two sets without any detectable glacimarine sediment cover. Tempelfjorden and Billefjorden have a single debris lobe, where the outermost parts are covered with about $2 \mathrm{~m}$ of glacimarine sediments. The debris lobe in Tempelfjorden is composed of slightly deformed and massive clayey silt with scattered clasts, whereas the upper lobe set in Borebukta comprises massive clayey silt with abundant clasts. The origins of the debris lobe sediments are inferred to be glacigenic diamicton and reworked older glacimarine deposits that were pushed and extruded from beneath the glacier, at the end of a glacial advance or surge, and during stagnation.
The transition zone between the terminal moraines and the debris lobes cannot be resolved on our high resolution seismic profiles. However, two possibilities for the relation between these two features are suggested (Fig. 17b-c): (a) the formation of the debris lobes may have occurred subsequently to the deposition of the terminal moraines (Fig. 17b); in that case, the debris lobe sediments may have moved along a slip plane on the distal slope of the terminal moraine; (b) the debris lobes might have formed synchronously during deposition of the terminal moraines (Fig. 17c). The distal stratified glacimarine sediments are derived from glacial meltwater streams, icebergs, as well as from rivers.

\section{Conclusions}

Several conclusions may be drawn from this integrated acoustic and coring investigation of glacigenic deposits in Spitsbergen fjords:

- Ice-marginal deposits in Tempelfjorden, Billefjorden, Yoldiabukta and Borebukta are represented by proximal basins with morainal ridges and hummocky moraines, bounded by terminal moraines deposited between around $1870 \mathrm{AD}$ and 1900 AD. Debris lobes are present beyond the terminal moraines. During their deposition, little or no basal erosion occurred. Draping acoustically stratified facies are present beyond, and to some extent beneath and above, the debris lobes.

- Tempelfjorden and Billefjorden, presently influenced by a single tidewater glacier, comprise small proximal basins with several morainal ridges. The debris lobes are covered with glacimarine sediments.

- In Tempelfjorden, the debris lobe comprises slightly deformed and massive clayey silt with scattered clasts. The distal glacimarine sediments are composed of stratified clayey silt with low ice-rafted debris content. They are suggested to be glacimarine varves. The average sedimentation rate for the glacimarine sediments in Tempelfjorden is $17 \mathrm{~mm} / \mathrm{yr}$ for the last 130 years.

- Yoldiabukta and Borebukta, presently influenced by two tidewater glaciers, comprise large proximal basins. Their debris lobes have no detectable cover of acoustically stratified sediments.

- Tongue-like features, as well as transverse, undulating sub-parallel ridges and downslopeoriented lineations on the debris lobe surfaces in Yoldiabukta and Borebukta were formed by sed- 
iment movement subsequently to the deposition of the lobes.

- In Borebukta, the upper debris lobe set comprises massive clayey silt with high abundance of clasts. The distal glacimarine sediments in Yoldiabukta are composed of clayey silt with high IRD content. The average sedimentation rate at the latter location is $0.6 \mathrm{~mm} / \mathrm{yr}$ for the last 2300 years.

- Relatively few clasts in the distal glacimarine sediments in Tempelfjorden, compared with Yoldiabukta, are explained by higher sedimentation from suspension, masking the IRD in Tempelfjorden.

- High rates of sedimentation in distal parts of Tempelfjorden (and Billefjorden), compared with Yoldiabukta (and Borebukta), are explained by high sediment supply from rivers.

- Differences in architecture and lithology between the ice-marginal deposits of polythermal Svalbard glaciers and temperate glaciers show that sediment delivery from temperate glaciers is more meltwater-controlled than from polythermal glaciers.

Acknowledgements.-L. Plassen was at the Dept. of Geology, University of Tromsø, at the time this research was carried out. This work was financially supported by the Research Council of Norway through their funding of the SPINOF programme (Sedimentary Processes and Palaeoenvironment in Northern Fjords). Jan P. Holm undertook the final preparation of the figures. Steinar Iversen was responsible for the acoustic data recording. Edel Ellingsen helped with X-radiographs, carbonate content measurements and some of the Sedigraph analyses. Critical comments of two reviewers improved the quality of the manuscript. We extend our most sincere thanks to these institutions and persons.

\section{References}

Bennett, M. R., Huddart, D., Glasser, N. F. \& Hambrey, M. J. 2000: Resedimentation of debris on an ice-cored lateral moraine in the High-Arctic (Kongsvegen, Svalbard). Geomorphology 35, 21-40.

Boulton, G. S. 1986: Push-moraines and glacier-contact fans in marine and terrestrial environments. Sedimentology 33, 677-698.

Boulton, G. S., van der Meer, J. J. M., Hart, J., Beets, D., Ruegg, G. H. J., van der Watern, F. M. \& Jarvis, J. 1996: Till and moraine emplacement in a deforming bed surgean example from a marine environment. Quat. Sci. Rev. 15, 961-987.

Cowan, E. A., Cai, J., Powell, R. D., Clark, J. D. \& Pitcher, J.
N. 1997: Temperate glacimarine varves: an example from Disenchantment Bay, southern Alaska. J. Sediment. Res. 67, 536-549.

Cowan, E. A., Seramur, K. C., Cai, J. \& Powell, R. D. 1999: Cyclic sedimentation produced by fluctuations in meltwater discharge, tides and marine productivity in an Alaskan fjord. Sedimentology 46, 1109-1126.

De Geer, G. 1910: Guide de l'excursion au Spitsberg. Excursion A1. (Guide to excursions on Spitsbergen A1.) Stockholm: XI International Geological Congress.

Dowdeswell, J. A. 1989: On the nature of Svalbard icebergs. J. Glaciol. 35, 224-234.

Dowdeswell, J. A., Drewry, D. J., Liestøl, O. \& Orheim, O. 1984: Airborne radio echo sounding of sub-polar glaciers in Spitsbergen. Nor. Polarinst. Skr. 182.

Elverhøi, A., Liestøl, O. \& Nagy, J. 1980: Glacial erosion, sedimentation and microfauna in the inner part of Kongsfjorden, Spitsbergen. Nor. Polarinst. Skr. 172, 33-58.

Elverhøi, A., Lønne, Ø. \& Seland, R. 1983: Glaciomarine sedimentation in a modern fjord environment, Spitsbergen. Polar Res. 1, 127-149.

Elverhøi, A., Svendsen, J. I., Solheim, A., Andersen, E. S., Milliman, J., Mangerud, J. \& Hooke, R. L. 1995: Late Quaternary sediment yield from the High Arctic Svalbard area. J. Geol. 103, 1-17.

Gilbert, R. 2003: Varves. In G. V. Middleton (ed.): Encyclopedia of sedimentology and sedimentary rocks. Pp. 764766. Dordrecht: Kluwer Academic Publishers.

Gilbert, R., Nielsen, N., Möller, H., Desloges, J. R. \& Rasch, M. 2002: Glacimarine sedimentation in Kangerdluk (Disko Fjord), west Greenland, in response to a surging glacier. Mar. Geol. 191, 1-18.

Glasser, N. F. \& Hambrey, M. J. 2001: Styles of sedimentation beneath Svalbard valley glaciers under changing dynamic and thermal regimes. J. Geol. Soc. 158, 697-707.

Hagen, J. O., Liestøl, O., Roland, E. \& Jørgensen, T. 1993: Glacier atlas of Svalbard and Jan Mayen. Nor. Polarinst. Medd. 129.

Hald, M., Dahlgren, T., Olsen, T.-E., \& Lebesbye, E. 2001: Late Holocene palaeoceanography in Van Mijenfjorden, Svalbard. Polar Res. 20, 23-35.

Hambrey, M. J., Bennett, M. R., Dowdeswell, J. A. Glasser, N. F. \& Huddart, D. 1999: Debris entrainment and transfer in polythermal valley glaciers. J. Glaciol. 45, 69-86.

Hamilton, G. S. \& Dowdeswell, J. A. 1996: Controls on glacier surging in Svalbard. J. Glaciol. 42, 157-168.

Huddart, D. \& Hambrey, M. J. 1996: Sedimentary and tectonic development of a High-Arctic, thrust-moraine complex: Comfortlessbreen, Svalbard. Boreas 25, 227-243.

Jiskoot, H. Murray, T. \& Boyle, P. 2000: Controls on the distribution of surge-type glaciers in Svalbard. J. Glaciol. 46, 412-422.

King, L. H. 1967: Use of conventional echo-sounder and textural analyses in delineating sedimentary facies: Scotian Shelf. Can. J. Earth Sci. 4, 691-708.

Korsun, S. \& Hald, M. 2000: Seasonal dynamics of benthic foraminifera in a glacially fed fjord of Svalbard, European Arctic. J. Foraminifer. Res. 30, 251-271.

Liestøl, O. 1969: Glacier surges in west Spitsbergen. Can. J. Earth Sci. 6, 895-898.

Lønne, I. 1995: Sedimentary facies and depositional architecture of ice-contact glaciomarine systems. Sediment. Geol. 98, 13-43.

Lyså, A. \& Vorren, T. O. 1997: Seismic facies and architec- 
ture of ice-contact submarine fans in high-relief fjords, northern Norway. Boreas 26, 309-328.

Mackiewicz, N. E., Powell, R. D., Carlson, P. R. \& Molnia B. F. 1984: Interlaminated ice-proximal glacimarine sediments in Muir Inlet, Alaska. Mar. Geol. 57, 113-147.

Mangerud, J. \& Gulliksen, S. 1975: Apparent radiocarbon ages of recent marine shells from Norway, Spitsbergen, and Arctic Canada. Quat. Res. 5, 263-272.

Mitchum, R. M. Jr., Vail, P. R. \& Sangree, J. B. 1977: Seismic stratigraphy and global changes of sea level. Part 6: stratigraphic interpretation of seismic reflection patterns in depositional sequences. In C. E. Payton (ed.): Seismic stratigraphy-applications to hydrocarbon explorations. Am. Assoc. Pet. Geol. Mem. 26, 117-133.

Ó Cofaigh, C. \& Dowdeswell, J. A. 2001: Laminated sediments in glacimarine environments: diagnostic criteria for their interpretation. Quat. Sci. Rev. 20, 1411-1436.

Powell, R. D. 1990: Glacimarine processes at grounding-line fans and their growth to ice-contact deltas. In J. A. Dowdeswell \& J. C. Scourse (eds.): Glacimarine environments: Processes and sediments. Geol. Soc. Lond. Spec. Publ. 53, 53-73.

Powell, R. D. \& Molnia, B. F. 1989: Glacimarine sedimentary processes, facies and morphology of the south-southeast Alaska shelf and fjords. Mar. Geol. 85, 359-390.

Praeg, D., MacLean, B., Hardy, I. A. \& Mudie, P. J. 1986: Quaternary geology of the south-east Baffin Island continental shelf, North West Territories. Geol. Surv. Can. Pap. $85-14$.

Sexton, D. J., Dowdeswell, J. A., Solheim, A. \& Elverhøi, A. 1992: Seismic architecture and sedimentation in northwest Spitsbergen fjords. Mar. Geol. 103, 53-68.

Solheim, A. 1991: The depositional environment of surging sub-polar tidewater glaciers. Nor. Polarinst. Skr. 194.

Solheim, A. \& Pfirman, S. L. 1985: Sea-floor morphology outside a grounded, surging glacier; Bråsvellbreen, Svalbard. Mar. Geol. 65, 127-143.

Stevens, R. L. 1990: Proximal and distal glacimarine depos- its in southwestern Sweden: contrasts in sedimentation. In J. A. Dowdeswell \& J. C. Scourse (eds.): Glacimarine environments: processes and sediments. Geol. Soc. Lond. Spec. Publ. 53, 307-316.

Stuiver, M., Pearson, G. W. \& Braziunas, T. F. 1986: Radiocarbon age calibration of marine samples back to $9000 \mathrm{cal}$ yr BP. Radiocarbon 28, 980-1021.

Stuiver, M., Reimer, P. J., Bard, E., Warren Beck, J., Burr G. S., Hughen, K. A., Kromer, B., McCormac, G., van der Plicht, J. \& Spurk, M. 1998: INTCAL98 radiocarbon age calibration, 24,000 - 0 cal BP. Radiocarbon 40, 1041-1083.

Svendsen, J. I., Elverhøi, A. \& Mangerud, J. 1996: The retreat of the Barents Sea Ice Sheet on the western Svalbard margin. Boreas 25, 244-256.

Svendsen, J. I. \& Mangerud, J. 1997: Holocene glacial and climatic variations on Spitsbergen, Svalbard. The Holocene 7, 45-57.

Syvitski, J. P. M. \& Praeg, D. B. 1989: Quaternary sedimentation in the St. Lawrence estuary and adjoining areas, eastern Canada: an overview based on the high resolution seismo-stratigraphy. Géogr. Phys. Quat. 43, 291-310.

Vorren, T. O., Lebesbye, E., Andreassen, K. \& Larsen, K. B. 1989: Glacigenic sediments on a passive continental margin as exemplified by the Barents Sea. In R. D. Powell \& A. Elverhøi (eds.): Modern glacimarine environments: glacial and marine controls of modern lithofacies and biofacies. Mar. Geol. 85, 251-272.

Warren, C. R. 1992: Iceberg calving and the glacioclimatic record. Prog. Phys. Geogr. 16, 253-282.

Werner, A. 1993: Holocene moraine chronology, Spitsbergen, Svalbard: lichenometric evidence for multiple Neoglacial advances in the Arctic. The Holocene 3, 128-137.

Whittington, R. J., Forsberg, C. F. \& Dowdeswell, J. A. 1997: Seismic and side-scan sonar investigations of recent sedimentation in an ice-proximal glacimarine setting, Kongsfjorden, north-west Spitsbergen. In T. A. Davies et al. (eds.): Glaciated continental margins. An atlas of acoustic images. Pp. 175-178. London: Chapman and Hall. 